\title{
WestVirginiaUniversity
}

THE RESEARCH REPOSITORY @ WVU

Graduate Theses, Dissertations, and Problem Reports

2002

\section{Imagery use in fencing}

Jason Michael Boron

West Virginia University

Follow this and additional works at: https://researchrepository.wvu.edu/etd

\section{Recommended Citation}

Boron, Jason Michael, "Imagery use in fencing" (2002). Graduate Theses, Dissertations, and Problem Reports. 1459.

https://researchrepository.wvu.edu/etd/1459

This Thesis is protected by copyright and/or related rights. It has been brought to you by the The Research Repository @ WVU with permission from the rights-holder(s). You are free to use this Thesis in any way that is permitted by the copyright and related rights legislation that applies to your use. For other uses you must obtain permission from the rights-holder(s) directly, unless additional rights are indicated by a Creative Commons license in the record and/ or on the work itself. This Thesis has been accepted for inclusion in WVU Graduate Theses, Dissertations, and Problem Reports collection by an authorized administrator of The Research Repository @ WVU. For more information, please contact researchrepository@mail.wvu.edu. 


\title{
IMAGERY USE IN FENCING
}

\author{
Jason M. Boron
}

Thesis submitted to the School of Physical Education

at West Virginia University in partial fulfillment of the requirements

for the degree of

\author{
Master of Science \\ in \\ Physical Education
}

\author{
Andrew Ostrow, Ph.D., Chair \\ Dana Brooks, Ed.D. \\ Sam Zizzi, Ed.D. \\ Department of Physical Education \\ Morgantown, West Virginia \\ 2002
}

Keywords: Imagery, Visualization, Fencing, SIQ, IUQ 


\section{ABSTRACT \\ Imagery Use in Fencing}

Jason M. Boron

The purposes of this study were to: (1) evaluate the motivational and cognitive components of imagery use among fencers, and (2) to determine if these motivational and cognitive components and the use of imagery among fencers is a function of skill level, experience, primary weapon, gender, or handedness. A survey containing the Sport Imagery Questionnaire (SIQ), Imagery Use Questionnaire (IUQ), and a brief demographic questionnaire were distributed to 132 male and 116 female fencers competing in the United States Fencing Association's 2000 Summer Nationals in Austin, TX. Psychometric characteristics of the SIQ were calculated and indicated that most items measured the predicted factors. The data from the SIQ were analyzed using multivariate analysis of variance. The results indicated that, regardless of the individual difference variable analyzed, fencers did not differ in motivational and cognitive components of imagery use. Additionally, trends in the IUQ scores were noted. 
Table of Contents

Introduction 1

$\begin{array}{ll}\text { Methods } & 7\end{array}$

$\begin{array}{ll}\text { Participants } & 7\end{array}$

$\begin{array}{ll}\text { Measures } & 7\end{array}$

$\begin{array}{lr}\text { Procedure } & 9\end{array}$

$\begin{array}{lr}\text { Pilot Study } & 9\end{array}$

$\begin{array}{ll}\text { Results } & 10\end{array}$

$\begin{array}{ll}\text { Discussion } & 13\end{array}$

Table 1: Demographic Characteristics of Fencing Sample $(N=248) \quad 19$

Table 2: Intercorrelation Matrix Describing the Relationship Between SIQ

$\begin{array}{ll}\text { Subscale Scores } & 20\end{array}$

Table 3: SIQ Subscale Principal Components Factor Analysis 21

Table 4: Intercorrelation Matrix Describing the Relationship Between SIQ

Subscale Scores to Demographic Variables 22

Table 5: MANOVA Analysis Examining Gender, Skill Level, Experience,

Weapon, and Weapon Hand in Relation to Fencers' Response

to SIQ 23

Table 6: Imagery Use Questionnaire Descriptive Statistics 24

Appendix I: Review of Literature $\quad 29$

Appendix II: Institutional Review Board Protocol Statement 53 
Introduction

Athletes have indicated that sports are physically as well as mentally demanding. The sport of fencing is no exception. Some of the greatest fencers have alluded to the mental demands that are placed on a fencer. Aldo Nadi (1943) stated that a fencer's weapon is simply an extension of a fencer's brain. Furthermore, Csaba Elthes went as far as to compare fencing to the art of chess because of the great mental demands of the sport (Westbrook \& Hazarika, 1997). Some athletes have stated that mental preparation is a vital part of training for competition and competition itself. Researchers have sought to determine the validity of these statements. Defrancesco and Burke (1997) surveyed professional tennis players about their use of mental preparation for competition. This study indicated that the elite athletes cited psychological skills more often as reasons for their successful performances in tournaments. According to this study, imagery was one of the most common mental strategies employed by the participating athletes.

Programs have been developed to help athletes build their psychological skills within the realm of sport. Many researchers found that these Psychological Skills Training (PST) programs were effective in improving athletic performance. These PST programs combine various skills (e.g., imagery, relaxation, and goal setting) with physical training in an effort to improve competitive performance. Researchers have evaluated PST programs to determine their effectiveness for performance enhancement in sport. These research studies (Daw \& Burton, 1994; Kendall, Hrycaiko, Martin, \& Kendall, 1990; Lerner, Ostrow, Yura, \& Etzel, 1996) indicated that sport performance significantly improved as a result of PST.

Research has also focused on programs that use only mental imagery. These PST programs provide athletes with basic knowledge of imagery use, such as techniques and 
types (e.g., internal, external, outcome). The goals of such programs are to increase and improve the use of imagery during sports participation. For example, Rogers, Hall, and Buckolz (1991) used an imagery intervention to train figure skaters. The participants demonstrated significant increases in the use of imagery and improvements in their performance on the ice. However, Van Gyn, Wenger, and Gaul (1990) concluded that imagery used in conjunction with physical practice will result in improvements in performance, and that imagery alone does not have this effect.

Imagery is a psychological skill that may help improve an athlete's performance. It is a multi-sensory experience in that images can include visual, auditory, olfactory, tactile, and kinesthetic components. In an attempt to determine the effectiveness of imagery, Driskell, Copper, and Moran (1994) performed a meta-analysis of previous research on mental practice, or imagery. The results indicated that imagery does have a significant effect on performance, albeit less than the effect of physical practice.

The theoretical support for why imagery is effective has evolved over several decades. A recent theory to explain imagery was proposed by Paivio (1985). He indicated that imagery has cognitive and motivational components that affect the individual. The four components that Paivio introduced were (1) motivation-specific (MS), (2) motivation-general (MG), (3) cognitive-specific (CS), and (4) cognitive-general (CG). The MS component of the theory refers to the use of goal-oriented responses. The effect of the MG component is the management of arousal level. The CS component of imagery taps into the improvement of perceptual-motor skills. The final component CG refers to the imagery of strategies used during the sport. Hall, Mack, Paivio, and Hausenblas (1998) discovered the existence of two subscales within the MG component of the model: arousal (MG-A) and mastery (MG-M). This model was further refined by 
Martin, Moritz, and Hall (1999) when they incorporated the meaning of an image, type of imagery, and individual differences. Evaluating the motivational and cognitive components of imagery is central to the current investigation.

Two of the principal image perspectives that athletes use are internal and external imagery. Internal imagery refers to the images that use the first person perspective, while external images are those that are visualized from the third person perspective, similar to watching a movie. Mahoney and Avener (1977) found that elite gymnasts who used internal imagery tended to perform better. Other research supports the theory that athletes use both perspectives and that there were no significant performance differences between those who used internal imagery and those who used external imagery (Gordon \& Weinberg, 1994; Hall, Rogers, \& Barr., 1990). Hall et al. (1990) also indicated that athletes tend to switch between perspectives depending on the demands of the situation. Glisky, Williams, and Kihlstrom (1996) discovered that the perspective the athlete uses would dictate the success of that athlete in a specific task, cognitive/visual or a motor/kinesthetic task. Therefore, the task may determine the most effective image for the athlete. Considering these and other findings, researchers have concluded that each athlete's imagery experience is individual (Hall, 1997; White \& Hardy, 1998).

Some additional characteristics can influence the impact that imagery may have on performance. Vividness and controllability are key components to consider when teaching individuals how to use imagery (Vealey \& Greenleaf, 1998). Vividness refers to the characteristics of an image (i.e., color, scents, emotional and physical feelings). According to Isaac (1992), research indicated that athletes with more vivid imagery, as measured by the Vividness of Visual Imagery Questionnaire and the Vividness of Movement Questionnaire, improved in performance when compared to those with low 
vividness imagery ability. However, Pie et al. (1996) concluded that vividness is not a determining factor in the effectiveness of an image. Controllability refers to the ability of an individual to manipulate an image that is being visualized. Smith (1987) felt that the more control over an image an athlete has, the more effective the image.

In a meta-analysis of research, Driskell, Copper, and Moran (1994) discovered that imagery may be affected by the type of task being imaged, the interval between practice and performance, and the length of time the athlete practiced using imagery. Furthermore, Martin, Moritz and Hall (1999) indicated that individual differences might also play a role in the effectiveness of the use of imagery for performance enhancement. Among the factors measured in this study are experience, skill level, gender, and handedness.

Experience can affect imagery use by providing an athlete with a greater pool of knowledge from which to draw information to form more realistic images (Barr \& Hall, 1992). The authors found that rowers with more experience tended to better image in their sport. Through a meta-analysis, Driskell, Copper, and Moran (1994) determined that previous experience may influence the effectiveness of mental practice, but only when the task was taken into consideration. Subjects with more experience benefited equally regardless of the type of task. However, novice subjects experience greater benefits when visualizing cognitive tasks as opposed to physical tasks.

Research indicates that skill level is also a factor when considering the effectiveness of imagery on physical performance. McCaffery and Orlick (1989) surveyed professional golfers, elite athletes in this sport, and discovered that imagery was an important part of mental preparations for golfers. Professional tennis players who finished in the top 20 of a tournament cited imagery as one of the preferred strategies to 
enhance one's performance (Defrancesco \& Burke, 1997). Furthermore, Pie et al. (1996) found that elite athletes may benefit more from the use of imagery than non-elite athletes. Elite athletes could more effectively integrate imagery into their training program. This may be a result of having a better grasp on the demands and skills in the sport, thus allowing them to better apply imagery to practice and competition.

Studies that have addressed imagery use as a function of gender have provided contradicting results. Burhans, Richman, and Bergey (1988) discovered that female athletes exhibited less stress than their male counterparts after imaging prior to competition. However, some research studies, while examining male or female participants, failed to evaluate imagery use differences across gender (e.g., Munroe, Hall, Simms, \& Weinberg, 1998).

Handedness is another individual difference variable that may be useful in evaluating the benefits of imagery use. Bisiacchi, Ripoli, Stein, Simonet, and Azmer (1985) examined the differences of left-handed and right-handed fencers. They found that left-handed fencers were typically better fencers and concluded that this may be due to the right-brain - left-hand connection. According to Longman and Atkinson (1999) right-brained individuals tend to better process visually and kinesthetically. Annett (1985) attempted to explain the relationship between handedness, speech, and cognitive ability through the Right-Shift Theory. This theory is based on a genetic characteristic that affects the processing in the right- and left-hemispheres of the brain. The implication that this theory has towards imagery is that people who are left-handed may have greater spatial cognitive ability. Research has indicated mixed results in this area. Natsopoulos and Kiosseoglou (1992) discovered that left-handed children had higher spatial ability than their right-handed counterparts. Overby (1990) studied imagery use in dancers and 
determined that imagery may not be hemisphere-specific. Other studies have also indicated that handedness could not be used to predict cognitive performance (Resch \& Haffener, 1997).

The present study was designed to examine the use of imagery in the sport of fencing. Studies have examined the use of imagery by athletes from many different sports. However, few studies have researched imagery use in the sport of fencing. One such study by Munroe, Hall, Simms, and Weinberg (1998) found that during the season, fencers significantly increased their use of imagery to help them in practicing mental strategies. Other studies, outside of fencing, have shown imagery may reduce anxiety, increase motivation, and/or increase physical performance (Burhans, Richman, \& Bergey, 1988; Martin \& Hall, 1995; Savoy \& Beitel, 1996, Vadocz, Hall, \& Moritz, 1997).

The primary purposes of this study were: (1) to evaluate the motivational and cognitive components of imagery use among fencers, and (2) to determine if these motivational and cognitive components of images among fencers are a function of skill level, experience, primary weapon, gender, or handedness. A secondary purpose was to evaluate the use of imagery among these fencers. To reach these goals this researcher proposed several research questions: Do fencers incorporate cognitive and motivational imagery into their sport? What individual difference variables affect what types of imagery fencers may use? Specifically, does imagery vary as a function of skill level, experience, primary weapon, gender, and handedness? To what extent do fencers use imagery in their sport? What types of imagery use habits do fencers form to assist them in the sport? A descriptive, correlational research design was employed to examine these research questions. 
Methods

\section{$\underline{\text { Participants }}$}

Participants were members of the United States Fencing Association (USFA) who competed in the USFA's 2000 Summer Nationals held in Austin, TX. These athletes were competing in Division IA, Division II, and/or Division III foil, epee, or saber events. The participants consisted of 132 male and 116 female fencers. Table 1 contains demographic information about the sample. The sample was comprised of $82 \%$ Caucasian, 5\% Asian, 4\% African-American and 9\% of those who indicated the "other" category. Right-handed fencers (81\%) greatly outnumbered those who were left-handed $(12.5 \%)$ and ambidextrous $(5.2 \%)$; the remaining $1.3 \%$ did not respond to the question. The fencers who completed the survey indicated that their primary weapon was epee (34.7\%), foil (43.7\%), or saber $(21.4 \%)$. The ages of the competitors ranged between 12 and 74 years old with a mean age of 28.42 years and standard deviation of 12.82 years. The average number of years fenced was $7.01(S D=6.98)$ and ranged between 0.5 years to 47 years. A number of different skill levels, as defined by USFA ratings, were represented at this competition: A (2.8\%), B (8.5\%), C (17.7\%), D (19.4\%), and E $(21.8 \%) ; 29 \%$ were unranked, and $0.8 \%$ did not respond to the question.

\section{$\underline{\text { Measures }}$}

Demographic Questionnaire: This questionnaire was designed to evaluate the individual difference variables of those who participated in the study. The demographic variables that were examined in this study were weapon class, USFA rating, years experience, age, gender, and handedness.

Sport Imagery Questionnaire: The Sport Imagery Questionnaire (SIQ; Hall et al., 1998) was developed to evaluate the motivational and cognitive functions of imagery. The SIQ 
is a 30-item questionnaire that uses a 7-point Likert scale to collect data on each of five constructs which the test measures: Motivational Specific (MS), Cognitive General (CG), Cognitive Specific (CS), Motivational General-Arousal (MG-A), and Motivational General-Mastery (MG-M). These subscales were devised based on the theory put forth by Paivio (1985).

Items were developed and then evaluated by a group of experts and elite athletes for content validity. The SIQ was then given to a group of athletes to evaluate its psychometric properties. The internal consistency of each subscale was estimated to be above an alpha coefficient of .70. After a principal components factor analysis was performed, each item was found to load on the correct factor, above .40 (Hall, 1998). This factor analysis determined that the five subscales were orthogonal. Imagery Use Questionnaire: The Imagery Use Questionnaire (IUQ; Hall et al., 1990) was used to assess various aspects of imagery use among the participants. It is a 37 -item survey with response choices using a 7-point Likert scale. Various research studies have used this survey and minor variations of it to evaluate imagery use in a number of sports ranging from rowing to soccer to figure skating (Barr \& Hall, 1992; Rogers et al., 1991; Salmon et al., 1994). According to Hall (1998), no psychometric data were collected on the original version of the IUQ. However, some psychometric data were evaluated on the IUQ developed for soccer players (IUQ-SP). The test-retest reliability coefficients for the IUQ-SP subscale items ranged between .55 and .95 over a 2- to 3- week period (Salmon et al., 1994). The subscale internal consistency coefficients for the items of the variation used by Salmon et al. (1994) ranged from .75 to 85 . For the purpose of this study, the short answer essay questions were removed from the survey. 


\section{$\underline{\text { Procedure }}$}

Approval was obtained for the study from the Institutional Review Board for the Protection of Human Subjects. The athletes volunteered to participate in the study. Fencers were recruited for the study through announcements and posted signs at the USFA's summer nationals at Austin, TX. Incentive was provided in the form of two drawings for gift certificates to a fencing supply company for all those individuals who completed the survey. Tables and chairs were set up in the large outer lobby of the convention center, the location of the tournament. This location was chosen because it was less crowded and more conducive to completing a survey. The area was not devoid of distractions, but it was the most ideal location available under the circumstances. The athletes would come to the table and sit to complete the questionnaire under the supervision of the investigator. First, they would read and sign the consent forms, sign the sign-in sheet, and finally begin the survey. The order of the questionnaires, SIQ and IUQ, was not counterbalanced because the primary focus of this study was on the athletes' responses to the SIQ and the researcher did not want the ordering to interfere with how the fencers responded to the SIQ.

\section{$\underline{\text { Pilot Study }}$}

A pilot study was performed to determine the viability of administering the IUQ and the SIQ. This pilot study included subjects from a midwestern university fencing club $(N=6)$. The study served several purposes. First, to determine which version of the IUQ to distribute for the larger study. Due to the limited psychometric research on the IUQ this researcher determined it was reasonable to shorten the survey by eliminating the short answer essay questions and removing those questions not directly related to the use of imagery. The second purpose was to determine any logistical questions that may arise 
during the actual administration of the larger study. The final purpose was to gather any feedback from the participants with regards to the survey questionnaire.

The pilot study revealed that the shortened version of the IUQ required approximately 5-10 minutes less time to complete. Due to anticipated time limitations at the USFA Summer Nationals, the modified version of the IUQ was included in the general survey packet. Feedback from the participants indicated that each survey questionnaire was clear and self-explanatory. In general, they stated that it was not difficult to complete the two instruments.

\section{Results}

It was hypothesized that: (1) in terms of skill level, elite fencers will score higher in CG, MG-A, and MS-M than non-elite fencers and non-elite fencers will score higher on CS than elite fencers, (2) there will be significant differences on the SIQ as a function of handedness and choice of primary weapon, although the direction of the difference was not predictable, and (3) gender will not affect the type of imagery used by fencers.

To test the hypotheses of the study, it was felt important to first examine the psychometric properties of the SIQ among this sample of fencers. First an intercorrelation matrix was calculated to determine the relationships between the SIQ subscales. The results of this matrix are found in Table 2. Statistically, all of the subscales significantly correlated with one another. However, the correlation coefficients were low to moderate, ranging from .20 to .63 .

The internal consistency of subjects' responses to each subscale of the SIQ was evaluated. Measures of Cronbach alpha were within an acceptable range: $\mathrm{MS}=.89$, MG-M $=.65, \mathrm{MG}-\mathrm{A}=.72, \mathrm{CG}=.80$, and $\mathrm{CG}=.75$, although the Cronbach alpha coefficient for MG-M was somewhat low. 
A principal components factor analysis was performed to examine the construct validity of the SIQ. Using a maximum likelihood extraction with a varimax rotation, the results indicated that most of the individual items loaded on the predicted factors (Table 3). Only loadings greater than .40 were included in Table 3 . The cumulative percent of variance accounted for by these five factors was $54.28 \%$. Four factors (A, B, C, and E) were discernable of the anticipated five factors corresponding to the subscales. Four of the six items that were predicted to load on factor D (CS) actually loaded on factor C (CG). The only subscale in which all of the items loaded as predicted was factor A (MS).

An intercorrelation matrix was established to determine the relationship between SIQ subscale scores and the demographic variables. The results indicated a few statistically significant but extremely low relationships (Table 4). Age and MS exhibited a statistically significant correlation with an $r$-value of -.13. Significant correlations also exist between gender and MG-M ( $r=.14)$ and MG-A $(r=.15)$. The individual's primary weapon was also related to the CG subscale $(r=.14)$.

To test the hypotheses of the study, several MANOVAs were computed to analyze the subscale scores on the SIQ with a $p<.05$. The results can be found in Table 5. The data were analyzed first using a 2 (Skill Level) x 2 (Experience) MANOVA. Skill level was determined through the use of the USFA classification scale. This scale ranged from A thru E; a rating of A being the best and $\mathrm{E}$ being the lowest. Fencers who were classified A, B, or C were included in the high skill group and the low skill group consisted of those fencers with ratings of D or F. A median split of years fenced was used to determine the high- and low-experience groups. The results indicated no significant multivariate main effect for Skill Level $\left[\right.$ Wilks $^{\prime} \Lambda=.97, F(1,1)=1.02, p>$ 
.05 ], Experience [Wilks' $\Lambda=.96, F(1,1)=1.22, p>.05]$, or for the Skill Level $\mathrm{x}$ Experience interaction $\left[\right.$ Wilks $\left.^{\prime} \Lambda=.96, F(1,1)=1.18, p>.05\right]$. A second 2 (Skill Level) x 2 (Gender) MANOVA showed no statistically significant results. The data analysis revealed no statistically significant main effect for Skill Level $[$ Wilks' $\Lambda=.98, F(1,1)=$ $.7, p>.05]$, Gender [Wilks' $\Lambda=.96, F(1,1)=1.23, p>.05]$, or for the Skill Level $\mathrm{x}$ Gender interaction [Wilks' $\Lambda=.95, F(1,1)=1.48, p>.05]$. The third data analysis, a 2 (Weapon Hand) x 3 (Weapon) MANOVA indicated that no significant differences in imagery use existed for the Weapon Hand main effect [Wilks' $\Lambda=.99, F(1,1)=.69, p>$ $.05]$, the Weapon main effect [Wilks' $\Lambda=.95, F(1,1)=1.18, p>.05]$, or the Weapon Hand $\mathrm{x}$ Weapon interaction [Wilks' $\Lambda=.97, F(1,1)=.68, p>.05]$.

Descriptive statistics were calculated for the IUQ (Table 6). Due to the lack of psychometric data on the IUQ, the analysis of the data was limited to observable trends and not examining the significance of the results. The IUQ contained multiple questions about the various aspects of imagery (e.g., perspective, imagery habits, etc.). Performing a data analysis on the results would not likely prove fruitful with such a diverse group of questions. The results indicate that fencers tended to use imagery more prior to and during an event than during practice. The athletes also indicated that they tended to use more internal imagery than external imagery.

There are some notable trends in what fencers do image when they are visualizing. First, they tended to image themselves winning an event more often than losing an event; they do not image themselves frequently during their pre-event routines. Furthermore, the results showed a trend that the fencers were able to break down images and view individual skills and parts of those skills. The fencers indicated that they used 
kinesthetic imagery, including being able to feel equipment, different muscles, and control over various parts of their bodies. Also, it would appear that fencers typically do not have regularly scheduled imagery sessions, nor do they have structured imagery sessions.

\section{Discussion}

In order to determine if the SIQ effectively measured the motivational and cognitive components of fencers, it was necessary to examine the reliability and validity of the SIQ. Previous studies have not evaluated this instrument on a large sample of fencers. The results indicated that the internal consistency of subjects' responses to the subscales of the SIQ was within an acceptable range.

The factor analysis did confirm that the items on the test generally loaded as intended on four of the five subscales of the SIQ. However, it is necessary to draw attention to the CS component. With only 2 of the 6 intended questions loading on this subscale and the remaining 4 items loading on the CG subscale, the adequacy of these subscales for fencers is questionable. While some items on the SIQ also failed to load on the appropriate factor, the CS and CG subscales were the most problematic. It is possible that the difference between the CS and the CG subscales is not as distinct for fencers. It is important to note that a high correlation existed between these two subscales as seen in Table 2. This high correlation supports the notion that these constructs are not independent. Many fencing skills are open skills. In other words, much of the bladework in fencing is dependent on an opponent's blade-work. Thus, individuals imaging specific skills may naturally incorporate strategy into images because fencing skills are dependent on an opponent's action or reaction. 
Two of the remaining three SIQ subscales, MS and MG-M, loaded according to expectations. These subscales were the most salient of the five subscales. Together they accounted for $38.27 \%$ of the variance, more than the other three subscales combined. Therefore, the results of this study lend support to the MS and MG-M subscales in the measurement of certain motivational aspects of the images that fencers use. Future research with fencers should examine the three remaining subscales to determine if they need further refinement.

Munroe, Hall, Simms \& Weinberg (1998) examined the influence of time on the SIQ subscale scores of athletes competing in various sports, including fencing, by observing athletes at different times during their competitive seasons. The results of the study showed a trend in fencers scoring lower on each of the subscales than athletes from other sports regardless of the time during the season. Future studies examining fencers may need to modify the problematic items, through the use of more fencing specific language, to better test the CS and CG components of the SIQ. Modifying these questions to include fencing terms and situations may provide better results. It is possible that the CG and CS components are so closely related that they may need combined because they may measure the same construct within the sport of fencing. The CS and CG subscales should be reexamined for future studies, especially those involving fencers.

Initially, it was anticipated that individual differences would factor into the outcome of this study. However, it is important to note that the correlation coefficients between age, experience, gender, skill level, weapon hand, or weapon with SIQ subscales were, for the most part, not statistically significant or extremely low.

Skill level had no bearing on fencers' responses to the SIQ. It was shown that the high skill fencers, those who were rated A, B, or C, did not differ from those rated D or 
E. The results of the present study show little support for the findings of previous research, such as Defrancesco and Burke (1997). The grouping by skill level may also factor into the results. Including $\mathrm{C}$ level fencers in the high skill group may have prevented adequate delineation between the two skill levels. Furthermore, it is necessary to consider the process by which a fencer attains a USFA rating. Fencers achieve their rating through competing in USFA sanctioned tournaments. The attainment of these classifications is dependent on how many people are competing and what they are classified. A fencer cannot lose his/her rating through poor performance. Therefore, there is not a distinct separation between USFA classifications. For example, one outstanding performance by a $\mathrm{B} / \mathrm{C}$ classified fencer can boost his/her rank to an $\mathrm{A}$ classification. However, that fencer may not typically fence at an A level. Therefore, the determination of a fencer's classification is not necessarily exact. Future research may choose to determine a better way to measure skill level, such as using the fencers' final standings or the current point standings for national competitions. However, using the current USFA classification system may be the most effective and efficient way to measure performance by an individual.

The study also found that handedness had no affect on the SIQ subscale scores among fencers. According to the results, left- and right-handed fencers did not differ in terms of the motivational and cognitive components of imagery. This may very well be an indication that imagery is not a function of handedness. However, it is important to consider that only 31 left-handed fencers completed the survey. Compared to the 203 right-handed fencers who participated in the survey, that number is very low. Note that 248 surveys were completed. However, only 234 individuals indicated their handedness. 
The last hypothesis indicating that gender had no bearing on imagery use, was supported by the results. Previous studies have indicated that gender does not affect imagery use. This study supported those findings.

Some trends on the IUQ were noticeable. Fencers tended to use imagery more before and during an event than any other time. In the future, performance enhancement specialists may want to encourage fencers to make an effort to incorporate imagery in various portions of their sport, including practice and post-competition. They also appeared to prefer internal imagery to external imagery. Another notable result was that fencers practiced imagery irregularly and in unstructured sessions. These results suggest that imagery use habits are not very well developed among this sample of fencers.

Several factors may have influenced the outcome of this study. First, the amount of knowledge of imagery use that the fencing population had may be limited and this lack of knowledge may have affected the outcome. The USFA publishes a quarterly magazine, Fencing, that typically contains an article on sport psychology. The article is a cursory presentation of an area of sport psychology, such as goal setting, and how it applies to fencing. There are entire books dedicated to these areas and it is very difficult to provide all of the useful information in a mere two pages of a magazine. However, Heil and Zealand (2001) recently published a training manual that incorporated imagery into a PST program targeting fencers. This manual addresses a gap in the education of fencers and will hopefully lead to better fencers, mentally as well as physically. This was a progressive move by the USFA to further enhance the performance of its members. Also, some coaches may incorporate imagery skills into training programs while others may believe that these skills are not useful and disregard them. This limited exposure may affect how much psychological skills training (including imagery training) a fencer 
may use. Ultimately, a lack of awareness about imagery may also have affected the data gathered from the SIQ questionnaire.

The results of this study offer some useful information for performance enhancement consultants. First, consultants should determine what type of psychological skills are being used by the athlete and possibly taught by the coach. This study suggests that imagery use is not a primary psychological skill used by fencers. Therefore, it may be necessary to teach basic imagery skills to the fencers and help them to develop an imagery program focused on their sport. The consultant should discuss the importance of using imagery during practice as well as during competition. Regularly scheduled and structured sessions would help the fencers enhance their mental skills and hopefully improve their physical performance. Consultants can also examine the individual athletes' uses of different imagery perspectives. The trends noticed in this study suggest that fencers prefer to use the internal perspective. However, it may be useful to teach fencers to use both types of perspectives so that they can determine which view works best for them.

Ultimately, the consultant can work with the fencers to develop their visualization skills to the point that they can use them to prepare for future events. The sport of fencing is well known for its long episodes of downtime during major competitions. Furthermore, these tournaments can stretch all day long in larger competitions. This is due, in large part, to managing and seeding a large number of fencers in multiple categories. Thus, the competitors need to find something to do during these, sometimes, long periods of time. Also, fencers can face any number of opponents during a competition; reviewing game films is not as advantageous as it is in some sports, such as football. Therefore, this time may be best utilized using imagery to prepare for upcoming 
bouts. Imagery would provide the fencers with versatility to prepare for specific fencers. Once the bout schedule has been announced the fencers can use imagery to prepare for different types of fencers that they may be fencing in the coming rounds. Using imagery in this way can help keep the fencers mentally sharp during a time where they could easily lose the mental edge. The consultant should help develop the individual's imagery skills to the point that they would be effective and efficient when needed by the fencer. This is why it is important for the fencer to structure and regularly schedule their visualizations sessions.

Future exploration of psychological skills in the sport of fencing may provide greater insight into this area. It may be useful to examine fencers' knowledge base in regards to psychological skills in general. It is possible that fencers use other psychological skills in their training, just not imagery. Fencers may have been exposed to other types of psychological skills and use them to enhance their performance. It would be useful for coaches and fencers to discover what types of psychological skills fencers do use so that they may help others apply those skills in training and competition.

Although the results of this study did not support several of the stated hypotheses, this study did evaluate a population that has not been examined in great detail. Little is known about the psychological skills of fencers. The sport is growing and as more people participate, the demand for sport psychologists and psychological skills training will continue to grow. 
Table 1: Demographic Characteristics of Fencing Sample $(N=248)$

\begin{tabular}{|c|c|c|c|c|}
\hline Demographic Variable & $n$ & $M$ & $S D$ & $\%$ \\
\hline Age & 239 & 28.42 & 12.82 & \\
\hline \multicolumn{5}{|l|}{ Gender } \\
\hline Male & 132 & & & 53.2 \\
\hline Female & 116 & & & 46.8 \\
\hline \multicolumn{5}{|l|}{ Ethnicity } \\
\hline African American & 9 & & & 3.6 \\
\hline Asian & 13 & & & 5.2 \\
\hline Caucasian & 202 & & & 81.5 \\
\hline Other & 21 & & & 8.5 \\
\hline Experience (years fenced) & 247 & 7.01 & 6.98 & \\
\hline \multicolumn{5}{|l|}{ Skill level (USFA Rating) } \\
\hline A & 7 & & & 2.8 \\
\hline B & 21 & & & 8.5 \\
\hline $\mathrm{C}$ & 44 & & & 17.7 \\
\hline $\mathrm{D}$ & 48 & & & 19.4 \\
\hline $\mathrm{E}$ & 54 & & & 21.8 \\
\hline Unrated & 72 & & & 29.0 \\
\hline \multicolumn{5}{|l|}{ Weapon Handedness } \\
\hline Epee - Right & 72 & & & 29.1 \\
\hline Epee - Left & 14 & & & 5.7 \\
\hline Foil - Right & 91 & & & 36.8 \\
\hline Foil - Left & 17 & & & 6.9 \\
\hline Saber - Right & 45 & & & 18.2 \\
\hline Saber - Left & 8 & & & 3.2 \\
\hline
\end{tabular}


Imagery Use 20

Table 2: Intercorrelation Matrix Describing the Relationship Between $\underline{\text { SIQ Subscale Scores }}$

SIQ Subscales

\begin{tabular}{llllll}
\hline SIQ Subscales & CG & CS & MG-M & MG-A & MG-S \\
\hline CG & & & & & \\
CS & $.63^{*}$ & & & \\
MG-M & $.53^{*}$ & $.45^{*}$ & & \\
MG-A & $.44^{*}$ & $.35^{*}$ & $.43^{*}$ & & \\
MS & $.20^{*}$ & $.35^{*}$ & $.37^{*}$ & $.41^{*}$ & \\
& & & & & \\
\end{tabular}


Table 3: SIQ Subscale Principal Components Factor Analysis $(N=247)$

Factor

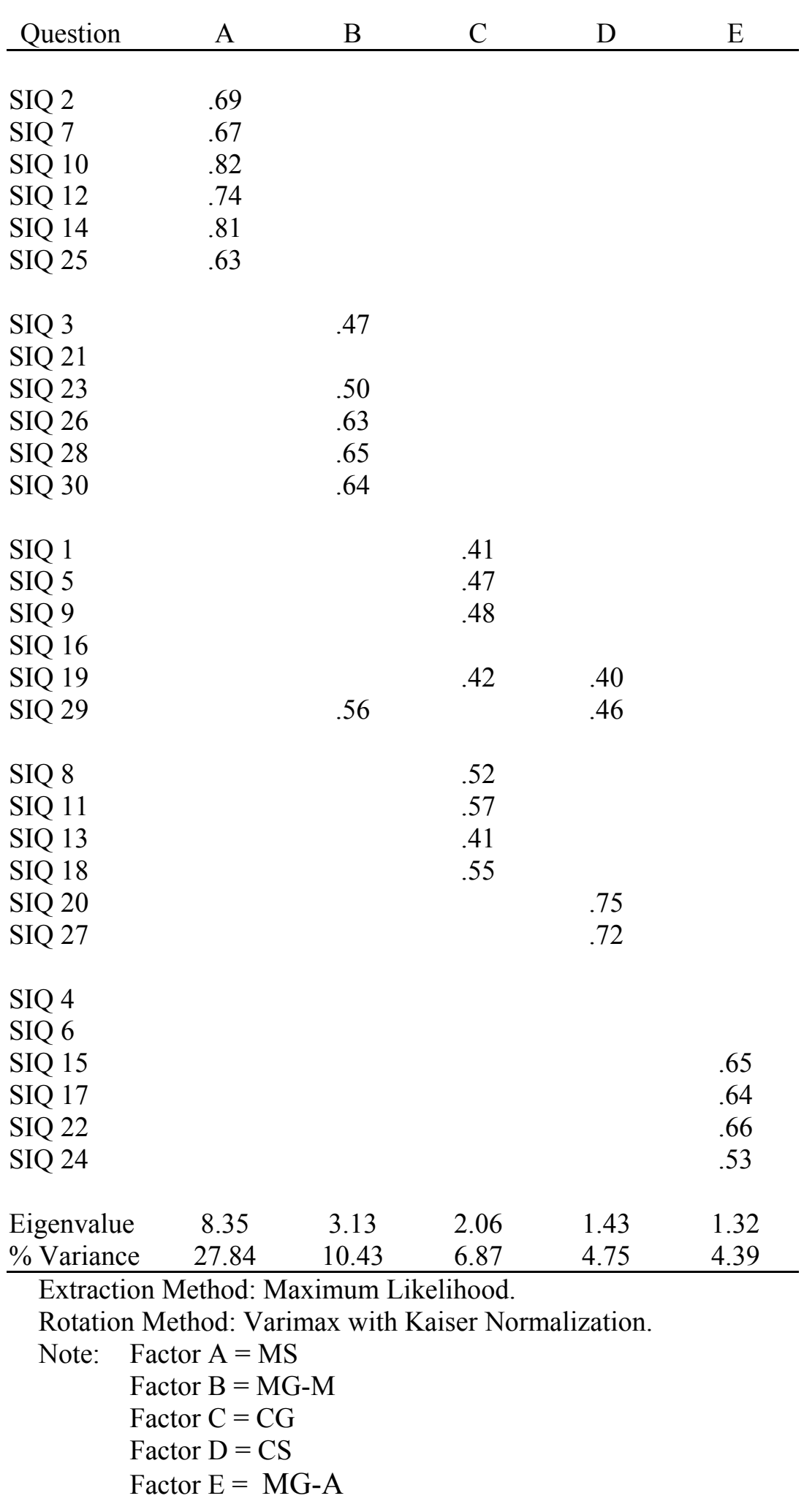


Table 4: Intercorrelation Matrix Describing the Relationship Between $\underline{\text { SIQ Subscale Scores to Demographic Variables }}$

\begin{tabular}{lccccc} 
& \multicolumn{5}{c}{ SIQ Subscales } \\
\cline { 2 - 6 } Demographic Variable & CG & CS & MG-M & MG-A & MS \\
\hline Age & -.11 & -.12 & -.08 & -.12 & $-.13 *$ \\
Experience (years fenced) & .04 & -.05 & .03 & .06 & -.14 \\
Skill Level (USFA Rating) & .10 & .13 & .12 & .08 & .02 \\
Gender & .12 & .04 & $.14 *$ & $.15 *$ & .02 \\
Weapon Hand & .01 & .00 & .10 & -.05 & -.05 \\
Weapon & $.14 *$ & .00 & .06 & .06 & .00 \\
\hline \multicolumn{1}{c}{$* 05$} & & & & &
\end{tabular}


Table 5: MANOVA Analyses Examining Gender, Skill Level, Experience, Weapon, and Weapon Hand in Relation to Fencers' Response to SIQ

\begin{tabular}{|c|c|c|c|c|c|}
\hline & $n$ & $d f$ & Wilks' $\Lambda$ & $F$ & Sig. \\
\hline Skill Level x Experience & 165 & & & & \\
\hline Skill Level & & 1 & .97 & 1.02 & .41 \\
\hline Experience & & 1 & .96 & 1.22 & .302 \\
\hline Skill Level x Experience & & 1 & .96 & 1.18 & .32 \\
\hline Skill Level x Gender & 162 & & & & \\
\hline Skill Level & & 1 & .98 & .70 & .62 \\
\hline Gender & & 1 & .96 & 1.23 & .30 \\
\hline Skill Level x Gender & & 1 & .95 & 1.48 & .20 \\
\hline Weapon Hand x Weapon & 237 & & & & \\
\hline Weapon Hand & & 1 & .99 & .69 & .63 \\
\hline Weapon & & 2 & .95 & 1.18 & .30 \\
\hline Weapon Hand x Weapon & & 2 & .97 & .68 & .74 \\
\hline
\end{tabular}


Table 6: Imagery Use Questionnaire Descriptive Statistics

\begin{tabular}{|c|c|c|c|}
\hline Question & $N$ & $M$ & $S D$ \\
\hline $\begin{array}{l}\text { To what extent do you use mental imagery } \\
\text { in your training? }\end{array}$ & 236 & 4.90 & 1.30 \\
\hline $\begin{array}{l}\text { To what extent do you use mental imagery } \\
\text { in your competition? }\end{array}$ & 235 & 5.02 & 1.32 \\
\hline \multicolumn{4}{|l|}{ Do you use mental imagery: } \\
\hline before a practice & 248 & 3.50 & 1.76 \\
\hline during a practice & 248 & 4.35 & 1.66 \\
\hline after a practice & 248 & 4.39 & 1.78 \\
\hline before an event & 248 & 5.12 & 1.63 \\
\hline during an event & 248 & 5.05 & 1.56 \\
\hline after an event & 248 & 4.89 & 1.74 \\
\hline during another unrelated activity & 248 & 4.27 & 1.82 \\
\hline during breaks in the day & 248 & 4.03 & 1.78 \\
\hline before/in bed & 248 & 4.39 & 1.94 \\
\hline $\begin{array}{c}\text { When you use mental imagery, do you see } \\
\text { yourself from outside of your body as if } \\
\text { you were watching yourself on a video? }\end{array}$ & 248 & 3.60 & 2.08 \\
\hline If you do, how vivid is the image? & 197 & 4.52 & 1.94 \\
\hline How easily can you change that image? & 196 & 4.47 & 1.76 \\
\hline $\begin{array}{l}\text { When you use mental imagery do you see } \\
\text { what you would see as if you were } \\
\text { actually playing or performing? }\end{array}$ & 248 & 5.20 & 1.70 \\
\hline If you do, how vivid is the image? & 241 & 5.16 & 1.43 \\
\hline How easily can you change that image? & 241 & 4.74 & 1.57 \\
\hline \multicolumn{4}{|l|}{$\begin{array}{l}\text { When you are imaging, how easily do you } \\
\text { see? }\end{array}$} \\
\hline isolated parts of a skill & 248 & 5.00 & 1.47 \\
\hline Entire skill & 248 & 5.14 & 1.35 \\
\hline part of an event & 248 & 4.89 & 1.50 \\
\hline entire event & 248 & 4.14 & 1.67 \\
\hline \multicolumn{4}{|l|}{$\begin{array}{l}\text { When you are imaging, how often do you } \\
\text { see: }\end{array}$} \\
\hline someone else performing & 248 & 3.38 & 1.84 \\
\hline yourself performing incorrectly & 248 & 3.28 & 1.63 \\
\hline yourself losing an event & 248 & 2.75 & 1.47 \\
\hline yourself doing a pre-event routine & 248 & 2.94 & 1.74 \\
\hline The atmosphere of the competition day & 248 & 3.98 & 1.86 \\
\hline Yourself winning an event & 248 & 4.60 & 1.69 \\
\hline Yourself receiving a first place award & 247 & 3.77 & 1.94 \\
\hline $\begin{array}{l}\text { When you are using mental imagery to what } \\
\text { extent do you actually feel yourself } \\
\text { performing? }\end{array}$ & 224 & 4.70 & 1.39 \\
\hline \multicolumn{4}{|l|}{ How easily do you feel: } \\
\hline specific muscles & 248 & 4.12 & 1.71 \\
\hline body control & 248 & 4.77 & 1.54 \\
\hline $\begin{array}{l}\text { Are your imagery sessions structured (i.e., } \\
\text { you know in advance what you will } \\
\text { image and for how long)? }\end{array}$ & 248 & 2.72 & 1.60 \\
\hline $\begin{array}{l}\text { Are you imagery sessions regular (i.e., at a } \\
\text { specific time each day)? }\end{array}$ & 248 & 2.21 & 1.40 \\
\hline $\begin{array}{l}\text { In preparation for your all-time best } \\
\text { performance, how much mental imagery } \\
\text { did you do? }\end{array}$ & 246 & 4.45 & 1.67 \\
\hline
\end{tabular}




\section{REFERENCES}

Annett, M. (1985). Left, right, hand and brain: The right shift theory. London, EN: Erlbaum.

Barr, K., \& Hall, C. (1992). The use of imagery by rowers. International Journal of Sport Psychology, 23, 243-261.

Bisiacchi, P.S., Ripoli, H., Stein, J.F., Simonet, P., \& Azmer, G. (1985). Lefthandedness in fencers: An attentional advantage. Perceptual and Motor Skills, 61, 507513.

Burhans, R.S., Richman, C.L., \& Bergey, D.B. (1988). Mental imagery training: Effects on running speed performance. International Journal of Sport Psychology, 19, 26-37.

Daw, J., \& Burton, D. (1994). Evaluation of a comprehensive psychological skills training program for collegiate tennis players. The Sport Psychologist, 8, 37-57.

Defrancesco, C., \& Burke, K.L. (1997). Performance enhancement strategies used in a professional tennis tournament. International Journal of Sport Psychology, 28, 185-195.

Driskell, J.E., Copper, C., \& Moran, A. (1994). Does mental practice enhance performance? Journal of Applied Psychology, 79, 481-492.

Glisky, M., Williams, J.M., \& Kihlstrom, J.F. (1996). Internal and external mental imagery perspectives and performance on two tasks. Journal of Sport Behavior, 19, 3-18.

Gordon, S, \& Weinberg, R. (1994). Effects of internal and external imagery on cricket performance. Journal of Sport Behavior, 17, 60-76. 
Hall, C.R. (1997). Lew Hardy's third myth: A matter of perspective. Journal of Applied Sport Psychology, 9, 310-313.

Hall, C.R. (1998). Measuring imagery abilities and imagery use. In J.L. Duda (Ed.), Advances in sport and exercise psychology measurement (pp. 165-172). Morgantown, WV: Fitness Information Technology, Inc.

Hall, C.R., Mack, D.E., Paivio, A., \& Hausenblas, H.A. (1998). Imagery use by athletes: Development of the Sport Imagery Questionnaire. International Journal of Sport Psychology, 29, 73-89.

Hall, C.R., Rogers, W.M., \& Barr, K.A. (1990). The use of imagery by athletes in selected sports. The Sport Psychologist, 4, 1-10.

Heil, J. \& Zealand, C. (2001) Psychological skills training manual. United States Fencing Assosication Technical Report (No. 2001-01). Colorado Springs, CO: United States Olympic Training Center.

Isaac, A. (1992). Mental practice - does it work in the field? The Sport Psychologist, 6, 192-198.

Kendall, G., Hrycaiko, D., Martin, G.L., \& Kendall, T. (1990). The effects of an imagery rehearsal, relaxation, and self-talk package on basketball game performance. Journal of Sport \& Exercise Psychology, 12, 157-166.

Lerner, B.S., Ostrow, A.C., Yura, M.T., \& Etzel, E.E. (1996). The effects of goal-setting and imagery training programs on the free-throw performance of female collegiate basketball players. The Sport Psychologist, 10, 382-397.

Longman, D.G., \& Atkinson, R.H. (1999). Study methods and reading techniques. Belmont, CA: Wadsworth Publishing Co. 
Mahoney, M.J., \& Avener, M. (1977). Psychology of the elite athlete: An exploratory study. Cognitive Therapy and Research, 1, 135-142.

Martin, K.A., \& Hall, C.R. (1995). Using mental imagery to enhance intrinsic motivation. Journal of Sport \& Exercise Psychology, 17, 54-69.

Martin, K.A., Moritz, S.E., \& Hall, C.R. (1999). Imagery use in sport: A literature review and applied model. The Sport Psychologist, 13, 245-268.

McCaffrey, N., \& Orlick, T. (1989). Mental factors related to excellence among professional golfers. International Journal of Sport Psychology, 20, 256-278.

Munroe, K., Hall, C., Simms, S., \& Weinberg, R. (1998). The influence of type of sport and time of season on athletes' use of imagery. The Sport Psychologist, 12, 440449.

Nadi, A. (1943). On fencing, Bangor, ME: Laureate Press.

Natsopoulos, D., \& Kiosseoglou, G. (1992). Handedness and spatial ability in children: further support for Gershwind's hypothesis of "pathology of superiority" and for Annett's theory of intelligence. Genetic, Social, and General Psychology Monographs, 118, 105-127.

Overby, L. (1990). A comparison of novice and experienced dancers' imagery ability. Journal of Mental Imagery, 14, 173-184.

Paivio, A. (1985). Cognitive and motivational functions of imagery in human performance. Canadian Journal of Applied Sport Sciences, 10, 22-28.

Pie, J.S., Tenenbaum, G., Bar-Eli, M., Eyal, N., Levy-Kolker, N., Sade, S., \& Landers, D. (1996). Imagery orientation and vividness: Their effect on a motor skill performance. Journal of Sport Behavior, 19, 32-49. 
Resch, F., Haffener, J, Parzer, P., Pfueller, U., Strehlow, U., \& Zerahn-Hatung, C. (1997). Testing the hypothesis if the relationship between laterality and ability according to Annett's right shift theory: Findings in an epidemiological sample of young adults. British Journal of Psychology, 88, 621-636.

Rogers, W., Hall, C., \& Buckolz, E. (1991). The effects of an imagery training program on imagery ability, imagery use, and figure skating performance. Journal of Applied Sport Psychology, 3, 109-125.

Salmon, J., Hall, C., \& Haslam, I. (1994). The use of imagery by soccer players. Journal of Applied Sport Psychology, 6, 116-133.

Savoy, C., \& Beitel, P. (1996). Mental imagery for basketball. International Journal of Sport Psychology, 27, 454-462.

Smith, D. (1987). Conditions that facilitate the development of sport imagery training. The Sport Psychologist, 1, 237-247.

Vadocz, E.A., Hall, C.R., \& Moritz, S.E. (1997). The relationship between competitive anxiety and imagery use. Journal of Applied Sport Psychology, 9, 241-253.

Van Gyn, G., Wenger, H., \& Gaul, C. (1990). Imagery as a method of transfer from training to performance. Journal of Sport \& Exercise Psychology, 12, 366-375.

Vealey, R.S., \& Greenleaf, C.A. (1998). Seeing is believing: Understanding and using imagery in sport. In J.M. Williams (Ed.), Applied Sport Psychology (pp. 237-269). Mountain View, CA: Mayfield Publishing Co.

Westbrook, P., \& Hazarika, T. (1997). Harnessing anger: The inner discipline of athletic excellence. New York, NY: Seven Stories Press.

White, A., \& Hardy, L. (1998). An in-depth analysis of the uses of imagery by high-level slalom canoeists and artistic gymnasts. The Sport Psychologist, 12, 387-403. 


\title{
CHAPTER 2
}

\section{REVIEW OF THE LITERATURE}

\author{
Introduction
}

The intention of this study is to determine the imagery use of fencers in relation to their gender, handedness, skill level, experience, and choice of primary weapon. There are no studies, to the knowledge of this researcher, that have been performed specifically in the area of fencing and imagery use. Some performance enhancement studies have included fencers as subjects, but they were only part of a larger group, and did not specifically target fencing (Cox, Liu, \& Qiu, 1996; Munroe, Hall, Simms, \& Weinberg, 1998). Due to the mentally and physically demanding characteristics of fencing, it appears to be a viable sport in which to investigate the imagery abilities of its participants.

This chapter is divided into the following sections: (1) The Psychology of Fencing, (2) Psychological Skills Training, (3) What is Imagery?, (4) Individual Difference Variables, and (5) Summary.

\section{The Psychology of Fencing}

There has been a multitude of books written about the sport of fencing, but few touch on the mental side of the sport. Aldo Nadi was one of the greatest fencers to participate in the sport. His book, On Fencing (Nadi, 1943), discussed the different physical aspects of fencing (i.e., attacks and parries), but did not discuss any specifics on mental training or techniques that could be used to enhance one's performance. The book was published in the middle of this century, when there was not a significant amount of information about the psychological aspects of sport. Although he did not 
state that mental training was necessary to compete in the sport, he did suggest that fencing is a mentally demanding sport. In one section of his book, Nadi stated that: Above everything else, fencing develops mental agility. Indeed, it is one of the few human activities in which, most of the time, lightning conception and execution are simultaneous. The fencer's blade becomes the extension of his fingers..., but the often expressed thought that it is also an extension of the mind is clearly an understatement. (p. 11)

Nadi emphatically implied that there is a great mental demand placed upon a fencer within a bout. According to Nadi, mental quickness is a must to compete in this sport. It would appear that many people agree that mental quickness is required for an individual to succeed in fencing. One coach, Csaba Elthes, went as far as to compare fencing to the art of chess because it requires such great mental agility (Westbrook \& Hazarika, 1997). Therefore, it is important that fencers learn psychological skills to possibly help build a mental edge in competition.

\section{Psychological Skills Training}

In general, sport psychologists have realized the importance of the mental side of sports and have begun to develop programs to enhance athletes' performances (i.e., PST programs). Research studies have investigated the viability of these programs. To a large extent, regardless of the type of skills introduced, the results indicate that PST programs are of benefit for the athletes who participate in them (Driskell, Copper, and Moran, 1994; Lerner, Ostrow, Yura, \& Etzel, 1996; Rogers, Hall, \& Buckolz, 1991). Typical PST programs incorporate several psychological skills; therefore, it is sometimes difficult to determine which part of the program had the most impact. Patrick and Hrycaiko (1998) discovered that the combination of skills (relaxation, imagery, self-talk, 
and goal setting) in a PST program resulted in an improvement in the endurance of the runners who participated in the study. Other studies have also indicated that there is a significant improvement in performance when psychological skills are applied by the athletes (Kendall, Hryaiko, Martin, Kendall, 1990; Savoy, 1993). These studies showed marked improvement of performers in their respective sports, significantly improving the performance statistics of the participants. Davis (1991), in a single subject research design study, developed a performance enhancement program for a tennis player. The results indicated that this PST program helped improve the individual's tennis specific skills. These studies support teaching psychological skills to fencers to possibly help improve their performance.

Although the idea of imagery has been around for many years, the use of imagery in sport has become a formalized technique only in the last several decades. It has been applied by a number of athletes in various sports. One study (McCaffery \& Orlick, 1989) surveyed professional golfers to determine their use of psychological skills within their sport. These professionals indicated that imagery was an important part of their mental preparation for practice and tournaments.

Some studies have shown that imagery may lead to improved physical performance. Driskell, Copper, and Moran (1994) performed a meta-analysis of current literature to determine how effective imagery was in relation to performance of a skill. The researchers determined that imagery use significantly improved performance. In a study that evaluated the effectiveness of imagery on dart throwing, Epstein (1980) discovered that imaging immediately prior to the task shows no significant improvement. Ille and Cadopi (1999) found that gymnasts performed better when they had better imagery skills. Another study by McKenzie and Howe (1997) discovered that imagery 
use can significantly improve self-efficacy levels, which, in turn, may affect performance. Savoy and Beitel (1996) used mental imagery to improve the foul shooting percentages of member of a women's basketball team. In another study that evaluated the effectiveness of imagery on anxiety, researchers found that imagery can be used to significantly reduce competitive anxiety and increase self-confidence (Vadocz, Hall, and Moritz, 1997). Although there were no direct performance appraisals, this study may have ramifications in improving performance through imagery by lowering levels of anxiety during competition.

Specific physical skills differ from sport to sport, yet imagery is a general skill that can be applied in a variety of sport situations. Therefore, though the images may change, the basic concept that mental imagery can enhance performances in different sports, ranging from football to tennis, and darts to fencing, remains constant. In fencing there are three different weapons from which one may choose: foil, epee, or saber. The strategies and mental preparation necessary for each weapon vary significantly, but imagery can be applied individually to help an athlete master the specifics of a weapon. What is Imagery?

Imagery is a technique that incorporates all of the senses to create images in one's mind. These images can be drawn from past experiences or they may be the creation of possible future experiences. It is important that these visualizations involve a multisensory approach. Images can include any number of senses. The most common sense in imagery use is the visual sense. People can also include information corresponding to their olfactory sense, tactile sense, auditory sense, or kinesthetic. The kinesthetic sense refers to the sensation of movement of the body. The more senses that are included in an image, then the image is much more vivid for the individual (Pie, et al., 1996). 


\section{Theoretical Framework}

No definitive reason has been established to explain why imagery works. There are a number of competing theories that attempt to explain why it does work. Vealey and Greenleaf (1998) summarized the major theories in the field: (1) psychoneuromuscular theory, (2) symbolic learning theory, and (3) a new model based on the combination of a model proposed by Paivio (1985) and several earlier theories. As indicated below, a number of research studies have been performed to test the validity of these theories.

The psychoneuromuscular theory, first established as early as 1931 by Jacobson (as cited in Vealey and Greenleaf, 1998), bases its explanation on the idea that when individuals imagine scenes, they also trigger the muscles that correspond to the movement involved in the scene. Suinn (1980) tested downhill skiers and discovered that when they image a race, their muscles fired in patterns that coincided with different portions of the race. Analysis of previous research by Driskell, Copper, and Moran (1994) disputes the foundation for the psychoneuromuscular theory. The authors felt that according to this theory, imagery would be more beneficial for physical tasks rather than cognitive tasks. However, their research suggests that imagery use is more effective for cognitive tasks.

The symbolic learning theory (Sackett, 1934, as cited in Vealey and Greenleaf, 1998) bases its assumptions on the idea that the use of imagery allows the athlete to create a mental blueprint of the skills that they are trying to learn. Therefore, through mental imagery, the athlete familiarizes himself/herself with the movements of a skill. Thus, this familiarity will allow that individual to better perform the skill. Feltz and Landers (1983) suggested that the effects of mental practice are due to the symbolic 
elements in the skill. Isaac (1992) also found support for this theory through the examination of the vividness of images used by trampolinists.

Before explaining the final model developed by Martin, Moritz, and Hall (1999) it is important to understand the model presented by Paivio (1985). Paivio based his model on the assumption that imagery has cognitive as well as motivational components. Each of these components can have general or specific behavior goals. The four components were (1) motivation-specific (MS), (2) motivation-general (MG), (3) cognitive-specific (CS), and (4) cognitive-general (CG). The MS component of the theory refers to the use of goal-oriented responses. The effect of the MG component is the management of arousal level. The CS component of imagery taps into the improvement of perceptualmotor skills. The final component is CG, which refers to the imagery of strategies used during the sport. Hall, Mack, Paivio, and Hausenblas (1998) further refined this model when they discovered that two subscales exist in the MG component of the model: arousal (MG-A) and mastery (MG-M).

Martin et al. (1999) felt that the psychoneuromuscular theory and the symbolic learning theory did an inadequate job of explaining why imagery is an effective intervention in sports. As stated previously, Paivio's model was designed to explain the impact of imagery on motor behavior in terms of its cognitive and motivational components. According to Martin et al., Paivio's model does not encompass all types of imagery that exist. Another weakness is that it cannot predict type of imagery use and its effects because it does not incorporate important factors such as situation or personal variables. It also fails to adequately predict which particular images can lead to changes in the behavior of an athlete. 
Therefore, Martin et al. (1999) developed a new model that draws ideas from Paivio's theory, the bioinformational theory, and Ashen's Triple-Code (ISM) Model of Imagery (1984). The bioinformational theory provided the authors with a framework to include physiological and emotional reactions to an athlete's images. Ashen (1984) developed the triple-code model to include the personal meaning attached to an image. In effect, the model proposed by Martin et al. explains the effects of imagery in terms of the type and meaning to the athlete and his/her cognitive, affective, and behavioral responses. This appears to be a strong model for explaining the impact of imagery.

\section{$\underline{\text { Controllability and Vividness }}$}

There are two characteristics of images that are key factors to consider when teaching imagery: controllability and vividness (Vealey \& Greenleaf, 1998). Daw and Burton (1994) included an imagery component into their PST program. The imagery was introduced via tapes that targeted physical and psychological components of their tennis game and emphasizing vividness and controllability. Controllability refers to the ability of the individual to control the image that he/she is visualizing. This is an important aspect of imagery because it allows the individual to manipulate the image, thus increasing its realism. The more control that athletes have over the images, the more beneficial they will be in enhancing their performance. Smith (1987) stated that control of an image gives the person doing the imaging better expectations about the outcome of possible scenarios. Therefore, he/she should perform better when having a more positive image experience rather than imaging an unsuccessful performance.

The concept of vividness is also important because it makes the image more realistic. This characteristic builds the image through detail, such as color, scents, and feelings (emotional and physical). These are skills that can be developed together 
through practice so that imagery can have greater impact on the person using the skill. In a study involving trampolinists, Isaac (1992) discovered that vivid imagery may enhance athletic performance. However, this finding was qualified in that the effectiveness was dependent on the assigned imagery task. Those who used more vivid imagery (high imagers), significantly improved when compared to the athletes who used less vivid imagery.

Although vividness is an important concept, one study indicated that it is not a determining factor in the effectiveness of an image (Pie et al., 1996). The authors discovered that the vividness of an image does not directly affect the performance of an individual. The researchers concluded that an individual can only benefit from imagery once he/she has mastered the skill. This could be due to the idea that more experienced athletes have a greater wealth of knowledge to draw from when forming their images. Therefore, their images may be more vivid, thus improving their effectiveness. Ultimately, this study indicated that other factors, such as experience, may have greater influence on physical performance.

Murphy (1990) reviewed various models of imagery present in the field of sport psychology. His article indicated that while vividness and controllability have been researched as the principal factors that determine the effectiveness of imagery use, that this may be shortsighted. Murphy states that there are other dynamic factors that need to be evaluated and that there are few instruments that can adequately document their effectiveness.

\section{Imagery Perspective}

When people visualize images, they tend to choose one of two perspectives: internal or external. Internal imagery refers to images that are from a first person 
perspective. Images occur as if seen through the eyes of the person who is doing the visualization. The other perspective, external imagery, involves images that are viewed from a third-person perspective, as if watching a movie (Mahoney \& Avener, 1977).

Studies have looked at athletes' use of imagery and which perspective they chose. Results from several studies indicate that there is a slight controversy as to which perspective is better to enhance one's performance. Mahoney and Avener (1977) found that elite gymnasts who used the internal perspective tended to be more successful. However, there are a number of studies with contradictory results. Hall, Rodgers, and Barr (1990) discovered that athletes tend to use both perspectives. They determined that elite and non-elite athletes use both perspectives, and did not favor one over the other. Another study by Gordon and Weinberg (1994) found that there were no significant differences between cricket players in a control group and the internal and external imagery groups. They also found similar results to Hall et al. (1990) in that the athletes indicated that they would switch between perspectives when imaging. Therefore, one perspective may not be better than the other. They also determined that athletes tend to switch between the two perspectives depending on what they are trying to accomplish. This may be due to the lack of experience of an athlete. A more experienced athlete may have more knowledge to draw from when creating images.

In an interesting study performed by Glisky et al. (1996) they discovered that the perspective taken, internal or external, would determine the success that an athlete would have in a specific task, cognitive/visual or a motor/kinesthetic task. The results indicate that athletes who used internal imagery performed better on the cognitive/visual task. The individuals who used external imagery performed better on the motor/kinesthetic task. The results of this study would appear to indicate that fencers could benefit from 
both types of imagery. They could use external imagery to correct problems and learn new moves. Internal imagery could be used to enhance their strategies in different situations. Epstein (1980) determined that an external perspective may provide athletes with a view that would allow them to critique themselves, thus improving their performance. Internal imagery could be applied to learn strategies and how to react to certain moves presented by opponents.

Pie et al. (1996) indicated that an athlete needs to experience a physical component in his/her imagery to make the visualization beneficial. Vividness is not as important as the ability to incorporate a kinesthetic component into imagery exercises. This study appears to support the literature that kinesthetic imagery is more effective at performance enhancement than just a visual image.

Hall (1997), one of the leading researchers in the area of imagery, indicated that the most important factor used to determine which perspective to use is the individual. Each person prefers his/her own approach to imagery and, therefore, needs to tailor imagery practice to preferences. Hall feels that athletes would benefit from using the perspective with which they feel the most comfortable. This is further supported by White and Hardy (1998) who discovered that each athlete's imagery experience is individual.

Imagery Type

There are two primary types of imagery people use when performing visualization exercises: outcome oriented and performance oriented.(Vealey \& Greenleaf, 1998) Outcome images involve seeing oneself at the end of a competition, typically winning the competition. Performance imagery tends to involve visualizing of the individual skills and portions of the competition. Both types of imagery serve separate functions. It has 
been indicated that the use of outcome images can serve as motivation for the athlete (Salmon et al, 1994). Through the increase in motivation to do well or win, an individual may experience an improvement in performance. Performance imagery allows the athlete to break down the physical skills that used in competition. This provides the individual with the opportunity to visualize any mistakes made in practice or competition.

It has been indicated by Hall (1997) that both types of imagery are of value in imagery practice. Studies show that beginning rowers use more outcome oriented imagery (Barr \& Hall, 1992). They may not have enough experience to form performance images. Elite athletes are more likely to have a broader base of experience to draw from when creating images (Pie et al, 1996). This could explain why there is a difference in the type of imagery used by beginners and elite athletes.

Rodgers et al. (1991) discovered that figure skaters often visualized themselves winning, including receiving the award. This study did not indicate the level (elite/nonelite) of the participants, other than that they ranged in ability. Hall et al. (1990) also discovered that athletes often imaged themselves winning and rarely imagined themselves losing. This type of imagery can serve as motivational and result in an improved performance.

\section{Frequency}

Another factor that may affect the impact that imagery has on one's performance is how often an individual uses imagery. There are a number of studies that have reported the imagery habits of different groups of athletes.

Hall et al. (1990) determined that athletes tend to use imagery more frequently when they are in competitive situations. This discovery is further supported by Rodgers et al. (1991) when they determined that before any formal imagery training was provided, 
the skaters in the study tended to use imagery before competitions. Typically, they did not use imagery during practice. Interestingly enough, Hall et al. (1990) also indicated that the athletes tended to report higher use of imagery prior to their best performance ever. Further support for athletes using imagery primarily prior to competition was established by Salmon, Hall, and Haslam (1994). They surveyed soccer players to determine imagery use in the sport. Results indicated that the participants tended to use imagery more in conjunction with competition than practice. Driskell, Copper, and Moran (1994), through a meta-analysis, theorized that an imagery program should include refresher courses every one or two weeks due to a decrease in the effectiveness of imagery after a two-week period. The researchers also determined that the amount of time in spent using imagery is not directly proportional to the gain in performance. This study indicated that 20 minutes appeared to be the most effective length of time.

\section{Individual Differences Variables}

Imagery use is influenced by attributes of the individual performing the task. These are characteristics that vary from individual to individual. The actual skill level may influence the type and use of imagery by an athlete. Experience is another factor that may affect the how athletes use imagery. Finally, gender and handedness may also factor into imagery use. Studies show that these variables may influence the impact that imagery has on the performance of a task.

\section{$\underline{\text { Skill Level }}$}

Athletes who participate in sport learn a number of physical skills. Typically, as athletes learn these skills they advance in their respective sports. Obviously, knowledge of skills alone will not make an elite athlete. There is another aspect that allows that athlete to excel at a sport. An athlete can spend years learning a sport only to achieve 
mediocrity. An athlete may know all of the skills that the sport demands of its participants, but he/she may not know how to make them flow together. It is in this flow state that an individual achieves their optimal level of arousal and is able to compete at an elite level (Jackson, 1995). Imagery can help the athlete by increasing the chances that the athlete will achieve this flow state. This state can be the difference between a medal and bad day of competition.

One can look at the various studies performed to determine what separates the elite and non-elite athletes. Aside from the physical skills that are acquired through practice, there are a number of mental characteristics that set the elite athlete apart from the non-elite athlete. Many elite athletes use mental preparations, such as imagery, to enhance their performance. Heishman and Bunker (1989) surveyed elite international female lacrosse players and discovered that they felt that mental preparation was an important part of competition. The results indicate that more successful athletes rely on mental preparation to a greater extent than less successful athletes.

Defrancesco and Burke (1997) distributed a questionnaire among the participants of a professional tennis tournament. Again, this survey included elite athletes from a variety of countries. This study indicated that a large majority of the athletes used performance enhancement strategies to prepare for competition. The players ranked in the top 20 also indicated that psychological skills played a greater role in their performance than those athletes who were ranked over 100 . In this study, imagery was one of the preferred strategies used to enhance one's performance. Another study, performed by McCaffery and Orlick (1989) surveyed professional golfers to determine which mental preparation strategies they preferred to use in their sport. The results support the idea that imagery plays an important role in psychological skills. The study 
determined that every athlete who was surveyed referred to imagery as a technique they used.

These studies appear to indicate that elite athletes find mental preparation strategies, specifically imagery, to be beneficial to their respective sports. The emphasis that they placed on psychological skills support the idea that these skills may further distinguish elite and non-elite athletes. These techniques may influence the performance level that an athlete can attain. Although it may be possible to achieve elite status without the psychological skills, these studies indicate that they go hand in hand.

Pie et al. (1996) investigated the use of imagery and how it would affect the performance of an eye-hand coordination task. The results provided an interesting view of successful imagery use among elite and non-elite individuals. They discovered that non-elite subjects needed to first learn the task at hand before trying to integrate imagery of the task in their training programs. Therefore, the researchers felt that imagery was only useful after an individual has effectively mastered the task. This study is indicative of the idea that fencers who are more skillful may benefit more from incorporating imagery into their practice sessions than would be a non-elite fencer. Therefore, elite fencers are more likely to be successful if they include imagery into their training program.

\section{Experience}

The amount of time that an athlete spends in a sport provides many opportunities for him/her to learn new skills and different strategies. Time provides an athlete with a chance to master sport specific skills and gain valuable strategic knowledge, especially in fencing. This individual difference is similar to skill level but it is not the same. Skill level is not directly dependent on the amount of time spent participating in a sport. There 
is likely a high correlation between time and skill level, but this relationship is not causal.

In the sport of fencing, experience can vary from a few months to a number of years.

Driskell, Copper, and Moran (1994) through a meta-analysis of literature determined that previous experience with a performance task can influence the effectiveness of mental practice. The authors defined mental practice as cognitively rehearsing a task before its performance. Driskell, Copper, and Moran found that experienced subjects benefited from both cognitive and physical tasks. However, novice subjects experiences greater benefits when focusing on cognitive tasks. Barr and Hall (1992) surveyed rowers and found that imagery use is more prevalent among athletes who have greater experience to draw from. This difference also affects the image content that they use when preparing for competition.

\section{Gender}

Imagery can also be affected by the gender of the athlete. Studies including males and females have produced mixed results. Barr and Hall (1992) discovered that male's rowers tended to have more control over external images than females. However, females appeared to practice imagery more often than males. This was explained by the fact that the women participating in the study had rowed longer and more competitively than there male counterparts. Therefore, this brings into question whether a gender effect exists. Another study (Munroe et al., 1998) concluded that there were no significant differences between males and females in the use of imagery. Therefore, they combined males and females into one group to be analyzed. Epstein (1980) noted that there was a significant difference in variability in improvement between genders following imagery sessions. Burhans, Richman, and Bergey (1988) indicated that female stress levels were significantly lower than male stress levels after imagery use prior to a competition. 
Overall, it was discovered that many imagery studies did not separate subjects according to gender. This could indicate that researchers feel that there are no gender differences in imagery use.

\section{$\underline{\text { Handedness }}$}

Fencers can fence either right- or left-handed. Bisiacchi, Ripoll, Stein, Simonet, \& Azmer (1985) discovered that left-handed fencers have a significance advantage over right-handed fencers. They felt this advantage was in attentional tasks and due to the lefthand -- right-brain connection. Wood and Aggleton (1989) examined this phenomenon in 'fast ball' sports and determined that left-handedness is merely a tactical advantage and offers no visio-spatial benefits. However, research has been attempting to reconcile this controversy for a long period of time. Natsopoulos and Kiosseoglou (1992) studied school children's spatial ability and concluded that a relationship does exist between handedness and spatial ability. Specifically, they found that left-handed children had superior spatial ability when compared to right-handed children. According to Longman and Atkinson (1999) right-brained individuals tend to better process visually and kinesthetically. Therefore, left-handed (right-brained) fencers may have different imagery abilities when compared with right-handed fencers. However, Overby (1998) examined female dancers' imagery abilities and determined that imagery may not be hemispheric-specific.

Annett (1985) presented the Right-Shift Theory to explain the relationship between handedness, speech, and cognitive ability. This theory is based on the existence of a gene that affects the processing in the right- and left-hemispheres of the brain. The implication that this theory has towards imagery is that people who are left-handed have greater spatial cognitive ability. This may indicate that left-handed (right-brained) 
fencers have a greater ability to image, which in turn implies that they could have a greater advantage if they would use imagery to enhance their performance. Natsopoulos and Kiosseoglou (1992) further supported Annett's theory by examining the spatial ability of 120 children: left-handed children outperformed right-handed children. This theory has faced a lot of opposition. Some studies have shown that the Right-Shift Theory does not hold true (Resch et al., 1997). The Resch et al. study could not confirm the existence of Annett's theory when it was applied to young adults.

\section{Summary}

There have been a variety of factors introduced in this chapter that influence the affect that imagery has on athletes. PST programs incorporate imagery into their program because it has been shown to improve performances when used in conjunction with physical practice. A number of theories have been developed to explain why imagery may influence physical performance: the psychonueromuscular theory, the symbolic learning, and Paivio's theory. Martin et al. (1999) felt that these theories failed to adequately explain the effects of imagery use and thus developed their own model that incorporates important aspects of other imagery theories. Vividness and controllability are important characteristics of imagery training of which athletes should be aware. The perspective (i.e., external vs. internal imagery) that an athlete chooses to use when imagining a scenario may affect the impact that an image will have on a performance. Therefore, athletes need to choose the perspective that is appropriate for the task at hand. Another factor that needs consideration is the type of imagery that is used: outcome imagery or performance imagery. Skill level may affect imagery use because elite fencers may have successfully incorporated imagery use in to their training. Experience may also influence imagery use because athletes may be able to draw more details from 
past bouts. Gender is another factor that may influence imagery use although there have been mixed results in determining if a relationship exists. The relationship between the hemispheres of the brain and an individual's dominant hand may affect imagery use.

Some studies indicate that they may influence the effectiveness of imagery practice on actual performance. It is the goal of this descriptive research study to determine the influence of these variables on imagery use. 


\section{REFERENCES}

Annett, M. (1985). Left, right, hand and brain: The right shift theory. London, EN: Erlbaum.

Ashen, A. (1984). ISM: The triple code model for imagery and psychophysiology. Journal of Mental Imagery, 8, 15-42.

Barr, K., \& Hall, C. (1992). The use of imagery by rowers. International Journal of Sport Psychology, 23, 243-261.

Bisiacchi, P.S., Ripoli, H., Stein, J.F., Simonet, P., \& Azmer, G. (1985). Lefthandedness in fencers: An attentional advantage. Perceptual and Motor Skills, 61, 507513.

Burhans, R.S., Richman, C.L., \& Bergey, D.B. (1988). Mental imagery training: Effects on running speed performance. International Journal of Sport Psychology, 19, 26-37.

Cox, R.H., Liu, Z., \& Qiu, Y. (1996). Psychological skills of elite Chinese athletes. International Journal of Sport Psychology, 27, 123-132.

Davis, Ken. (1991). Performance enhancement program for a college tennis player. International Journal of Sport Psychology, 22, 140-164.

Daw, J., \& Burton, D. (1994). Evaluation of a comprehensive psychological skills training program for collegiate tennis players. The Sport Psychologist, 8, 37-57.

Defrancesco, C., \& Burke, K.L. (1997). Performance enhancement strategies used in a professional tennis tournament. International Journal of Sport Psychology, 28, $185-195$.

Driskell, J.E., Copper, C., \& Moran, A. (1994). Does mental practice enhance performance? Journal of Applied Psychology, 79, 481-492. 
Epstein, M.L. (1980). The relationship of mental imagery and mental rehearsal to performance of a motor task. Journal of Sport Psychology, 2, 211-220.

Feltz, D.L., \& Landers, D.M. (1983). The effects of mental practice on motor skill learning and performance: A meta-analysis. Journal of Sport Psychology, 5, 25-57.

Glisky, M., Williams, J.M., \& Kihlstrom, J.F. (1996). Internal and external mental imagery perspectives and performance on two tasks. Journal of Sport Behavior, 19, 3-18.

Gordon, S, \& Weinberg, R. (1994). Effects of internal and external imagery on cricket performance. Journal of Sport Behavior, 17, 60-76.

Hall, C.R. (1997). Lew Hardy's third myth: A matter of perspective. Journal of Applied Sport Psychology, 9, 310-313.

Hall, C.R., Mack, D.E., Paivio, A., \& Hausenblas, H.A. (1998). Imagery use by athletes: Development of the Sport Imagery Questionnaire. International Journal of Sport Psychology, 29, 73-89.

Hall, C.R., Rogers, W.M., \& Barr, K.A. (1990). The use of imagery by athletes in selected sports. The Sport Psychologist, 4, 1-10.

Heishman, M.F., \& Bunker, L. (1989). Use of mental preparation strategies by international elite female lacrosse players from five countries. The Sport Psychologist, 3, 14-22.

Ille, A., \& Cadopi, M. (1999). Memory for movement sequences in gymnastics: Effects of age and skill level. Journal of Motor Behavior, 31, 290-301.

Isaac, A. (1992). Mental practice - does it work in the field? The Sport Psychologist, 6, 192-198. 
Jackson, S.A. (1995). Factors influencing the occurrence of flow states in elite athletes. Journal of Applied Sport Psychology, 7, 138-166.

Kendall, G., Hrycaiko, D., Martin, G.L., \& Kendall, T. (1990). The effects of an imagery rehearsal, relaxation, and self-talk package on basketball game performance. Journal of Sport \& Exercise Psychology, 12, 157-166.

Lerner, B.S., Ostrow, A.C., Yura, M.T., \& Etzel, E.E. (1996). The effects of goal setting and imagery training programs on the free-throw performance of female collegiate basketball players. The Sport Psychologist, 10, 382-397.

Longman, D.G., \& Atkinson, R.H. (1999). Study methods and reading techniques. Belmont, CA: Wadsworth Publishing Co.

Mahoney, M.J., \& Avener, M. (1977). Psychology of the elite athlete: An exploratory study. Cognitive Therapy and Research, 1, 135-142.

Martin, K.A., \& Hall, C.R. (1995). Using mental imagery to enhance intrinsic motivation. Journal of Sport \& Exercise Psychology, 17, 54-69.

Martin, K.A., Moritz, S.E., \& Hall, C.R. (1999). Imagery use in sport: A literature review and applied model. The Sport Psychologist, 13, 245-268.

McCaffrey, N., \& Orlick, T. (1989). Mental factors related to excellence among professional golfers. International Journal of Sport Psychology, 20, 256-278.

McKenzie, A.D., \& Howe, B.L. (1997). The effect of imagery on self-efficacy for a motor skill. International Journal of Sport Psychology, 28, 196-210.

Munroe, K., Hall, C., Simms, S., \& Weinberg, R. (1998). The influence of type of sport and time of season on athletes' use of imagery. The Sport Psychologist, 12, 440449. 
Murphy, S. (1990). Models of imagery in sport psychology: a review. Journal of Mental Imagery, 14, 153-172.

Nadi, A. (1943). On fencing, Bangor, ME: Laureate Press.

Natsopoulos, D., Kiosseoglou, G. (1992). Handedness and spatial ability in children: Further support for Gershwind's hypothesis of a pathology of superiority and for Annett's theory of intelligence. Genetic, Social \& General Psychology Monographs, $118,105-127$.

Overby, L. (1990). A comparison of novice and experienced dancers' imagery ability. Journal of Mental Imagery, 14, 173-184.

Paivio, A. (1985). Cognitive and motivational functions of imagery in human performance. Canadian Journal of Applied Sport Sciences, 10, 22-28.

Patrick, T.D., \& Hrycaiko, D.W. (1998). Effects of a mental training package on an endurance performance. The Sport Psychologist, 12, 283-299.

Pie, J.S., Tenenbaum, G., Bar-Eli, M., Eyal, N., Levy-Kolker, N., Sade, S., \& Landers, D. (1996). Imagery orientation and vividness: Their effect on a motor skill performance. Journal of Sport Behavior, 19, 32-49.

Resch, F., Haffener, J, Parzer, P., Pfueller, U., Strehlow, U., \& Zerahn-Hatung, C. (1997). Testing the hypothesis if the relationship between laterality and ability according to Annett's right shift theory: Findings in an epidemiological sample of young adults. British Journal of Psychology, 88, 621-636.

Rogers, W., Hall, C., \& Buckolz, E. (1991). The effects of an imagery training program on imagery ability, imagery use, and figure skating performance. Journal of Applied Sport Psychology, 3, 109-125. 
Ryan, E.D., \& Simons, J. (1982). Efficacy of mental imagery in enhancing mental rehearsal of motor skills. Journal of Sport Psychology, 4, 41-51.

Salmon, J., Hall, C., \& Haslam, I. (1994). The use of imagery by soccer players. Journal of Applied Sport Psychology, 6, 116-133.

Savoy, C. (1993). A yearly mental training program for a college basketball player. The Sport Psychologist, 7, 173-190.

Savoy, C., \& Beitel, P. (1996). Mental imagery for basketball. International Journal of Sport Psychology, 27, 454-462.

Smith, D. (1987). Conditions that facilitate the development of sport imagery training. The Sport Psychologist, 1, 237-247.

Suinn, R.M. (1980). Psychology and sport performance: Principles and applications. In R.M. Suinn (Ed.), Psychology in sports: Methods and applications (pp. 26-36). Minneapolis: Burgess.

USFA Homepage: www.usfa.org Vadocz, E.A., Hall, C.R., \& Moritz, S.E. (1997). The relationship between competitive anxiety and imagery use. Journal of Applied Sport Psychology, 9, 241-253.

Vealey, R.S., \& Greenleaf, C.A. (1998). Seeing is believing: Understanding and using imagery in sport. In J.M. Williams (Ed.), Applied Sport Psychology (pp. 237-269). Mountain View, CA: Mayfield Publishing Co.

Westbrook, P., \& Hazarika, T. (1997). Harnessing anger: The inner discipline of athletic excellence. New York, NY: Seven Stories Press.

White, A., \& Hardy, L. (1998). An in-depth analysis of the uses of imagery by high-level slalom canoeists and artistic gymnasts. The Sport Psychologist, 12, 387-403. 
Imagery Use 52

Wood, C., Aggleton, J. (1989). Handedness in 'fast ball' sports: do left handers have an innate advantage? British Journal of Psychology, 80, 227-240. 
Imagery Use 53

\section{Section A}

\section{Protocol Statement}


DO NOT WRITE IN THIS SPACE

H.S.\#

\section{Institutional Review Board Protocol Statement}

1. Title of study: Imagery Use in Fencing

2. Investigators

(list all investigators, principal investigator first; attach additional sheets if necessary);

\begin{tabular}{|c|c|c|c|c|}
\hline Name (type or print) & Dept/College & PO Box & Tel. No. \\
\hline Jason Boron & & $\begin{array}{l}\text { Sport Psychology/ } \\
\text { Physical Education }\end{array}$ & 6116 & (304) 599-7562 \\
\hline & & & & \\
\hline & & & & \\
\hline & & & & \\
\hline & & & & \\
\hline
\end{tabular}

Fax No.

3. Review category requested: $\square$ Quorum $\underline{\mathbf{X}}$ Expedited

(specify categories, see pp.7-9 of guidelines 6 )

4. Estimated period of human subject involvement: Starting date: $4 / 7 / 00$ Ending date: $4 / 9 / 00$

5. Reason for conducting research: $\square$ Professional $\square$ Dissertation $\underline{\underline{\mathbf{x}}}$ Thesis

ㄱ. Class Assignment $\square$ Other (specify)

6. Investigators at institutions other than WVU or units of the Health Sciences Center:
Institutional Affiliation
Name
Title
Role in Study

none

7. Persons other than the investigators who will have contact with subjects:

Name Title Degrees(s)

none

8. Persons other than the investigators who will obtain informed consent:
Name
Title
Degrees(s)

none

9. Persons other than the investigators who will have contact with data:

\begin{tabular}{|c|c|c|}
\hline Name & Title & Degrees(s) \\
\hline Andrew Ostrow & Program Coordinator & Ph.D. \\
\hline Frank Perna & Professor & Ed.D. \\
\hline
\end{tabular}

10. Location for interaction with subjects (provide name of institution, address, and brief deseription): International Exposition Center 6200 Riverside Dr. Cleveland, OH 44135

This will be the site for the United States Fencing Association's (USFA) competition. The address for the

USFA national office is One Olympic Plaza Colorado Springs, CO 80909-5774. 
11. Indicate with $a \sqrt{ }$ which of the following special populations will be targeted in the research:

Patients

Children (under 18)

Intellectually or emotionally impaired subjects

Elderly subjects (over 65)

Pregnant subiects or fetuses

Prisoners, parolees, incarcerated subjects

Illiterate subjects

Students or trainee:

Employees of institutions associated with the study

Employees or subordinates of investigators
12. Indicate by a $\sqrt{ }$ if any of the following items are involved:

Data collected from data banks, archives, modical records Data to be stored in data banks - arehives, medical records Filming, videotaping, or voice.recording of subjects

Questionnaires

or diagnostic tissue or fluids

Placental tissue

Fetal tissue

Approved drug or device in non-FDA-approved application -

Placebo(s)

Deception of subjects

13. Method of obtaining informed consent:

X_written consent form (include a copy in Section C)

_waiver or alteration of consent process (explain in Section C)

control group consent

14. Method of obtaining assent from children (age 7-18) or subjects unable to sign legally valid consent:

$\mathbf{X}$ _ written assent form (include a copy in Section C)

no assent, under age 7 or severely impaired (explain in Section C)

_control group assent

_ waiver or alteration of assent process (explain in Section C)

15. Will investigational drugs or devices be used?

yes $\quad X_{n}$ no If yes: IND\#

or IDE

16. Source of funding support: self Anticipated funding period:

Funding status: $\square$ Pending $\square$ Active (OSP \# )

Application deadline:

17. Will there be any financiat remuneration, reward. reimbursement of expenses or other inducements to participate?
$\mathrm{X}$ yes
$-{ }^{\text {no }}$
(If yes, explain in item 3 of Discussion.)

18. Will there be any potential added cost to subjects?

yes $\quad$ __no $^{\text {no }}$ (If yes, explain in item 4 of Discussion.)

19. Will you use a recruitment ad?
$\mathbf{X}$ yes
no
(If yes, attach a copy.)

20. Signatures: (The Board will not review the protocol without these signatures. By signing, department chairs acknowledge approval of this study on the basis of scientific merit and compliance with applicable professional standards: deans and other administrators signify their approval of the use of resources and faculty and student effort on the study. Multi-unit protocols require the signatures of each chair and dean,)

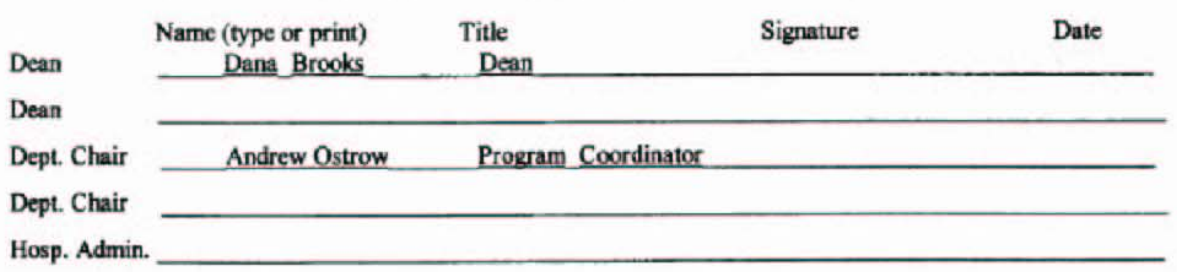


Section B

Abstract 
Imagery Use 57

\section{Imagery Use in Fencing}

In recent years, more emphasis has been placed on the mental side of sports. Performance enhancement specialists have worked with athletes to try and improve their performance in their sports. One of the methods used is imagery. Research has been performed in this area, but no studies have targeted fencers specifically. This study is designed to evaluate how fencers use imagery before, during, and after competition. In addition, the motivational and cognitive components of imagery use will be examined. The proposed study intends to survey approximately 300 subjects ( 150 male, 150 female) using the Imagery Use Questionnaire (IUQ), the Sport Imagery Questionnaire (SIQ), and a brief demographic questionnaire. This survey will be distributed at a United States Fencing Association (USFA) competition. When the fencers register for the competition, they will be given an advertisement for the survey. A curtained off area will be available where the fencers will complete the questionnaires during the event. 


\section{Section C}

\section{Consent and Assent Forms}




\section{CONSENT AND INFORMATION FORM}

\section{Imagery Use in Fencing}

I,

have been invited to participate in this research study performed by Jason Boron. Mr. Boron has explained the study to me and that this research is being conducted to fulfill the requirements for his master's thesis in Sport Psychology at West Virginia University

The purpose of this study is to learn more about the use of imagery in fencing This study will involve the completion of several questionnaires (the Imagery Use Questionnaire, the Sport Imagery Questionnaire, and a brief demographic questionnaire) which will take approximately 15 minutes to complete. I have been provided the opportunity to review the questionnaire prior to completion. I understand that I do not have to answer every question, but realize that my knowledge in this area is vital to a successful study. About 300 individuals will participate in this study.

There are no known or expected risks from participating in this study. I understand that this study is not intended to be of direct benefit to me, although the knowledge gained may benefit other individuals. For more information on this research, I can contact Jason Boron, at (304) 599-7562, or his advisor, Dr. Andrew Ostrow at (304) 293-3295 ext. 268. For more information regarding my rights as a research participant I may contact the Executive Secretary of the Institutional Review Board at West Virginia University at (304) 293-7073

I understand that any information about me obtained through this study will remain as confidential as legally possible. Neither my name nor any other identifying information obtained during this research will be published without my consent

My participation in this study is voluntary and I understand that I am free to withdraw from this study at any time. There will be no penalty if I choose not to participate or withdraw during the study. I have had the opportunity to ask any questions I have about the research being conducted and have received answers concerning those areas I did not understand.

I have the option to not participate in this study.

I understand that upon completion of the questionnaires my name, along with the names of the other participants in the study, will be entered into a lottery to win either a $\$ 100$ or $\$ 50$ gift certificate to a fencing supply store. I have been informed that I will be contacted within two weeks if I won a gift certificate.

Upon signing this form I will receive a copy for my records.

MTST MTGAMA UNIVERSTI instittion Review Bosed for the

I willingly consent to participate in this research.

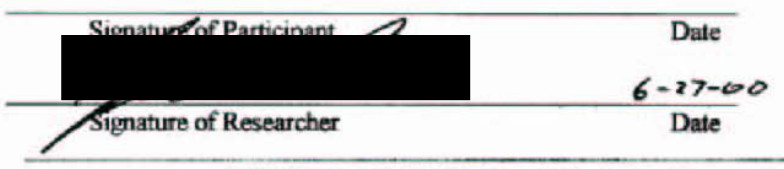

JUN 52000

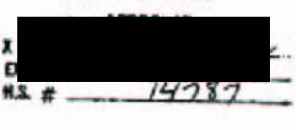

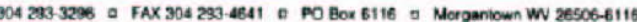




\section{PARENTAL or GUARDIAN CONSENT and INFORMATION FORM}

\section{Imagery Use in Fencing}

I, , have been asked to allow my child to participate in this study. Jason Boron, who is conducting this research to fulfill requirements for a master's thesis in Sport Psychology at West Virginia University, has explained the study to me

The purpose of this study is to learn more about the use of imagery in fencing. This study will be performed at a United States Fencing Association toumament. My child will be asked to complete a set of questionnaires, which will take approximately 15 minutes to complete. I have been given the opportunity to examine the questionnaires. My child understands that he/she does not have to answer every question, but it is important to the success of the study that they answer as many as possible. Approximately 300 individuals will participate in this study

There are no know or expected risks for participating in this study.

I understand that this study is not expected to be of direct benefit to my child, but the knowledge gained may be of benefit to others. For more information about this research, I can contact Jason Boron at (304) 599-7562 or his advisor, Dr. Andrew Ostrow at (304) 293-3295 ext 268 . For information regarding my child's rights as a research subject, 1 may contact the Executive Secretary of the Institutional Review Board at (304) 293-7073.

I understand that any information obtained as a result of my child's participation in this research will be kept as confidential as legally possible. My name or that of my child or any information from which we might be identified may not be published without my consent

I understand that participation in this study is completely voluntary and that I may withdraw my child from this study at any time. I further understand that refusal to participate will not result in any penalties. I have been given the opportunity to ask questions about the research concerning the areas 1 did not understand

My child has the option to not participate in this study.

I understand that upon completion of the questionnaire, my son/daughter will be entered into a lottery for a chance to win either a $\$ 100$ or $\$ 50$ gift certificate to a fencing supply store. I have also been informed that my son/daughter will be contacted within two weeks if they have won a gift certificate.

Upon signing this form 1 received a copy

I willingly consent to my child's participation in this research.

WIST VIRGINA UNVENSIT

Institution keview Barrt for mo protrition of Hurman Research Suliacte

JUN 52000

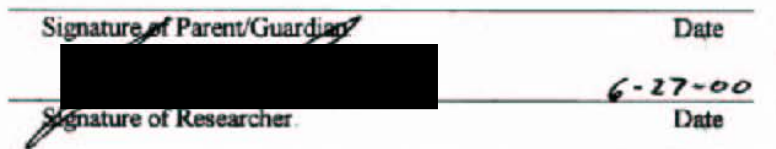

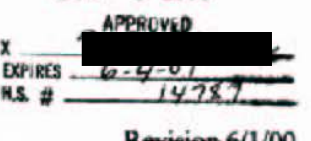

Revision 6/1/00

304 293-3296 D FAX 304 293-4641 a PO Box 6116 8 Morganiown WV 26506-6116 


\section{West Virginia University}

Athletic Coaching Education • Athletic Training • Physical Education • Sport Management • Sport Psychology

\section{ASSENT FORM}

\section{Imagery Use in Fencing}

I. have been asked to be in this research study, which has been explained to me by Jason Boron

I have been told that the purpose of this study is to learn more about the use of imagery in fencing.

This study will be performed at a United States Fencing Association tournament in which I am participating. I will be given several lists of written questions to answer. It will take about 15 minutes to complete this questionnaire. I do not have to answer all of the questions.

Some of the questions may be difficult and I may not enjoy answering them. The words used in the questions may not be clear and if I am confused by a word I can ask Mr. Boron to explain.

I understand that this study is not expected to help me, but what they learn from this study may help other people.

1 have been promised that anything that they learn about me in this study will be kept as secret as possible.

I have been told that I do not have to do this. I have been allowed to ask questions about the research, and all of my questions were answered.

I have been told that after I finish answering the questionnaire I will be entered into a lottery where I will have the chance to win either a $\$ 100$ or $\$ 50$ gift certificate to a fencing supply store.

I willingly agree to be in this research

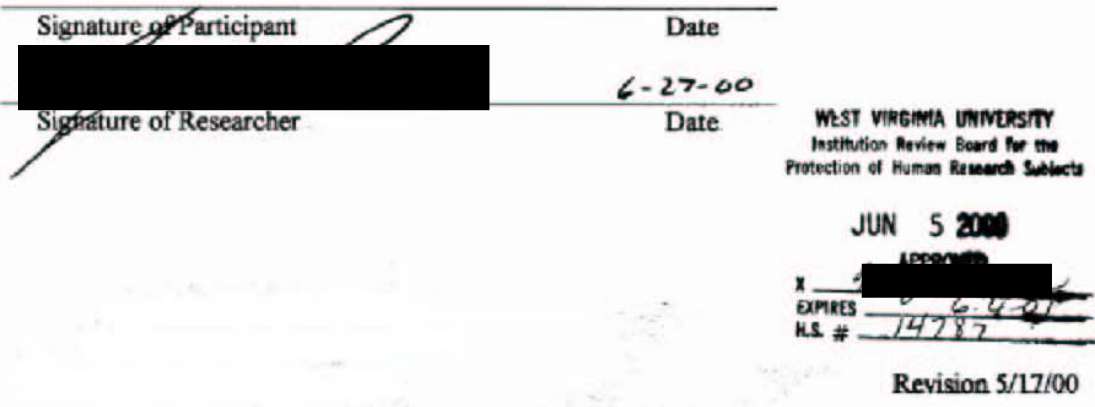

304283.3296 a FAX $304293-4641$. PO Bax 611E o Morgardom WV 26506-6116 
Imagery Use 62

\section{Section D}

Discussion 
D. Discussion

1. Purposes and Procedures

The objective of this study is to determine the use of imagery by fencers.

This survey will also indicate the cognitive and motivational aspects of the imagery used. These variables will be assessed as a function of experience, handedness, gender, age, and weapon choice. The questionnaires (Sport Imagery Questionnaire, Imagery Use Questionnaire, and a brief demographic questionnaire) will be distributed at a United Stated Fencing Association competition. The participants will complete the questionnaire in a curtained-off area to limit distractions and reduce possible error.

2. Subjects

The subjects in this study will number approximately 300 (150 men, 150 women). There are no restrictions on who can participate, other than they must be competing in the designated open events (men's foil, men's epee, men's saber, women's foil, women's epee, women's saber). Fencers who compete in the open events must be at least 13 years of age. The subjects will receive an advertisement promoting the survey when they register for the competition.

3. Payments to Subjects

If the subjects participate in the survey, they will be entered into a drawing to win one of two gift certificates ( $\$ 50$ or $\$ 100$ ) to a fencing equipment vendor.

4. Costs to subjects

There will be no cost to the participants other than 12-20 minutes of their time.

5. Benefits

Once the data are analyzed, any information discovered could lead to improved training techniques by coaches or performance enhancement specialists. This research will also help build the limited research in imagery use and martial arts such as fencing.

6. Risks and Discomforts

There are no known risks associated with this survey.

7. Radiation

N/A

8. Infectious Agents or Biohazards

N/A 
9. Future Additional Information

No further information will be distributed to the participants once they have completed the survey.

10. Adverse Events

No adverse events are anticipated, although any that would oceur would be reported to the IRB immediately.

11. Deception

N/A

12. Debriefing

N/A

13. Intervention

N/A

14. Confidentiality

Confidentiality will be maintained because the survey will not identify subjects. Anonymity and confidentiality will be ensured.

15. Principal investigator

The principal investigator, Jason Boron, is a graduate student in Sport Psychology and is seeking his master's degree. He holds a BA from Notre Dame in psychology. He has been involved in previous studies during his time at WVU. He assisted Dr. Perna in a research study exploring imagery use in basketball. Also, he worked with another student on a study for Dr. Brooks that examined the demand characteristics of football positions in a youth football league

16. Other investigators

Dr. Andrew Ostrow will advise Jason Boron on the study and the data analysis. Dr. Ostrow holds a $\mathrm{PhD}$ and is the Program Coordinator and a Professor in the Sport Psychology Program at WVU.

17. Other Participants

Dr. Frank Perna is a professor at WVU in the Sport Psychology Program and will assist in data analysis. 


\section{Section E}

\section{Attachments}


Dear Fencer:

I am writing to ask that you spend a few moments to complete a brief questionnaire about your use of imagery in fencing. I am collecting data for the completion of my master's thesis at West Virginia University.

The primary purpose of this research study is to determine the use of imagery by fencers.

This questionnaire is being distributed to members of the United States Fencing Association who are participating in the open events at this North American Circuit. Participation in this survey is voluntary. However, your experience in fencing is a critical factor in the completion and accuracy of this study.

This survey will take about fifteen to twenty minutes to complete. You do not need to answer all the questions, although your response is vital to a successful study. I appreciate your time and cooperation in the completion of this survey

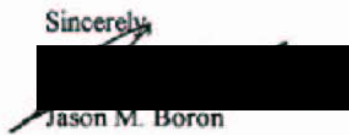

Department of Sport Psychology West Virginia University

Morgantown, WV 26506-6116

(304) $599-7562$

WEST VIRGWHA UNIVERSTT

Institution Review Borre for the Prolection of Human Research Sutiects

JUN 52000

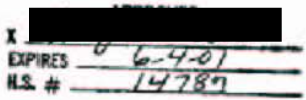


Age: Gender. MALE/FEMALE

Revised 6/9/00

Ethnicity: AFRICAN-AMERICAN / ASIAN / CAUCASIAN / OTHER (ptease specify)

Are you ( RIGHT-HANDED / LEFT-HANDED / AMBIDEXTROUS)?

What is your primary weapon (the one you are best at)? EPEE/FOIL/SABER

With which hand do you fence your primary weapon? RIGHT / LEFT

How many years have you been fencing?

What is you USFA rating? A / B / C / D / E / U

Have you competed today? YES / NO

\section{Spert Imagery Questionnaire}

Athletes use mental imagery extensively in their training and in conjunction with competition. Imagery serves two functions. The motivational function of imagery can represent emotion-arousing situations as well as specific goals and goal-oriented behaviors. The cognitive function entails the mental rehearsal of skills and strategies of play. A strategy is a plan or method of achieving some goal. In sport, this often is referred to as a game plan. For example, playing a pressure game to create turn-overs is a possible strategy to use in basketball, and this could be done by executing various skills and tactics (i.e., skills put together in a sequence) such as presses and man-on-man defenses. Another example of a strategy would be playing a baseline game in tennis: how this is actually accomplished (i.e., the skills performed) would vary considerably over the course of a game.

This questionnaire was designed to assess the extent to which you incorporate imagery into your sport. Any statement depicting a function of imagery that you rarely use should be given a low rating. In contrast, any statement describing a function of imagery that you use frequently should be given a high rating. Your ratings will be made on a seven-point scale, where one (1) is the rarely or never engage in that kind of imagery end of the seale and seven (7) is the often engage in that kind of imagery end of the scale. Statements that fall within these two extremes should be rated accordingly along the rest of the scalc. Read each statement below and fill in the blank the appropriate number from the scale provided to indicate the degree to which the statement applies to you when you are practicing or competing in your sport. Don't be concerned about using the same numbers repeatedly if you feel they represent your true feelings. Remember, there are no right or wrong answers, so please answer as accurately as possible.

Please fill in the blank or circle the appropriate answer according to the following scale:

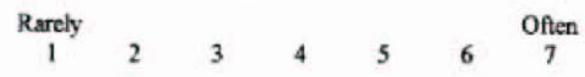

(1) I make up new plans/strategies in my head.

(1)

(2) I image the atmosphere of winning a championship (e g., the excitement that follows winning a

$$
\text { championship). }
$$

(3) 1 image giving $100 \%$ during an eventigame

(3)

(4) I can re-create in my head the emotions I feel before I compete.

(4)

(5) 1 image altemative strategies in case my event/game plan fails

(5)

(6) 1 imagine myself handling the stress and excitement of competitions and remaining calm. (6)

(7) I imagine other athletes congratulating me on a good performance. 


$\begin{array}{cccccccc}\begin{array}{c}\text { Rarely } \\ 1\end{array} & 2 & 3 & 4 & 5 & 6 & 7\end{array}$

(8) I can consistently control the image of a physical skill.

(8)

(9) I image each section of an event/game (e.g., offense vs. defene, fast vs. slow).

(9)

(10) 1 image the atmospbere of receiving a medal (e.g., the pride, the excitement, etc.)

(10)

(II) I can easily change an image of a skill.

(11)

(12) I image the audience applauding my performance.

(12)

(13) When imaging a particular skill, I consistently perform it perlectly in my mind

(13)

(14) I image myself winning a modal.

(14)

(15) I imagine the stress and anxiety associated with competing.

(15)

(16) I image myself continuing with nry game/event plan, even when performing poorly.

(17) When I image a competition, I feel nyself getting emotionally excited.

(16)

(18) I can mentally make corrections to physical skills

(17)

(19) I imagine executing entire plays/programs/sections just the way I want them to happen in an

$$
\text { event/game. }
$$

(20) Before attempting a particular skill, I imagine myself performing it perfectly.

(20)

(21) I imagine nyself being mentally tough.

(21)

(22) When I image an event/game that I am to participate in, I feel anxious.

(22)

(23) I imagine myself appearing self-confident in front of my opponents.

(23)

(24) I imagine the excitement associated with competing.

(24)

(25) I image myself being interviewed as a champion.

(25)

(26) I image myself to be focused during a challenging situation.

(26)

(27) When learning a new skill, 1 imagine myself performing it perfectly,

(27)

(28) I imagine myself being in control in difficult situations.

(28)

(29) 1 imagine myself successfully following my game/event plan.

(29)

(30) 1 image myself working successfully through tough situations (e.g., a power play, sore ankle, etc.). 
Many athletes go through their event or stages of it in their minds before actually competing. Mental imagery is a method of seeing yourself in action or seeing the action as you would perform but in your mind's eye (visualization). It can also include sensations and feelings associated with an action or the atmosphere and environment surrounding an event. This is a questionnaire designed to assess the USE of mental imagery. There are no right or wrong answers, but please try to answer as accurately as possible. In the following questions where a scale is given, please circle the appropriate number corresponding to your degree of imagery use.

1. To what extent do you use mental imagery in your training?

$$
\begin{array}{ccccccc}
1 & 2 & 3 & 4 & 5 & 6 & \begin{array}{c}
7 \\
\text { never }
\end{array}
\end{array}
$$

2. To what extent do you use mental imagery in your competition?
neve
23
5
7
always

3. Do you use mental imagery:

\begin{tabular}{|c|c|c|c|c|c|c|c|}
\hline a) before a practice & $\begin{array}{r}1 \\
\text { never }\end{array}$ & 2 & 3 & 4 & 5 & 6 & $\begin{array}{c}7 \\
\text { always }\end{array}$ \\
\hline b) during a practice & $\begin{array}{r}1 \\
\text { never }\end{array}$ & 2 & 3 & 4 & 5 & 6 & $\begin{array}{c}7 \\
\text { always }\end{array}$ \\
\hline c) after a practice & $\begin{array}{r}1 \\
\text { never }\end{array}$ & 2 & 3 & 4 & 5 & 6 & $\begin{array}{c}7 \\
\text { always }\end{array}$ \\
\hline d) before an event & $\begin{array}{r}1 \\
\text { never }\end{array}$ & 2 & 3 & 4 & 5 & 6 & $\begin{array}{c}7 \\
\text { always }\end{array}$ \\
\hline e) during an event & $\begin{array}{r}1 \\
\text { never }\end{array}$ & 2 & 3 & 4 & 5 & 6 & $\begin{array}{c}7 \\
\text { always }\end{array}$ \\
\hline f) after and event & $\begin{array}{r}1 \\
\text { never }\end{array}$ & 2 & 3 & 4 & 5 & 6 & $\begin{array}{c}7 \\
\text { always }\end{array}$ \\
\hline $\begin{array}{l}\text { g) during another } \\
\text { unrelated activity } \\
\text { (e.g., running) }\end{array}$ & $\begin{array}{r}1 \\
\text { never }\end{array}$ & 2 & 3 & 4 & 5 & 6 & $\begin{array}{c}7 \\
\text { always }\end{array}$ \\
\hline $\begin{array}{l}\text { h) during breaks } \\
\text { in the day }\end{array}$ & $\begin{array}{r}1 \\
\text { never }\end{array}$ & 2 & 3 & 4 & 5 & 6 & $\begin{array}{c}7 \\
\text { always }\end{array}$ \\
\hline i) before/in bed & $\begin{array}{r}1 \\
\text { never }\end{array}$ & 2 & 3 & 4 & 5 & 6 & $\begin{array}{c}7 \\
\text { always }\end{array}$ \\
\hline
\end{tabular}


4. When you use mental imagery, do you see yourself from outside of your body as if you were watching yourself on a video?

$$
\begin{array}{rrrrrrr}
1 & 2 & 3 & 4 & 5 & 6 & \begin{array}{c}
7 \\
\text { always }
\end{array}
\end{array}
$$

If you do, how vivid is the image?

$$
\begin{array}{ccccccc}
\text { I } & 2 & 3 & 4 & 5 & 6 & \begin{array}{c}
7 \\
\text { not vivid }
\end{array} \\
& & & & & \text { very detailed }
\end{array}
$$

How easily can you change that image?

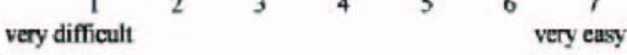

5. When you use mental imagery do you see what you would see as if you were actually playing or performing?

$\begin{array}{rrrrrrr}1 & 2 & 3 & 4 & 5 & 6 & \begin{array}{c}7 \\ \text { never }\end{array}\end{array}$

If you do, how vivid is the image?

$$
\begin{array}{ccccccc}
1 & 2 & 3 & 4 & 5 & 6 & \begin{array}{c}
7 \\
\text { not vivid }
\end{array} \\
& & & & & \text { very detailed }
\end{array}
$$

How easily ca you change that image?

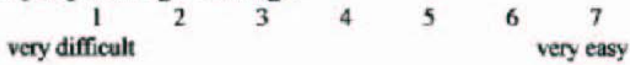

\begin{tabular}{|c|c|c|c|c|c|c|c|}
\hline $\begin{array}{l}\text { a) someone else performing } \\
\text { (c.g., to imitate) }\end{array}$ & $\begin{array}{r}1 \\
\text { never }\end{array}$ & 2 & 3 & 4 & 5 & 6 & $\begin{array}{c}7 \\
\text { always }\end{array}$ \\
\hline b) yourself performing incorrectly & $\begin{array}{r}1 \\
\text { never }\end{array}$ & 2 & 3 & 4 & 5 & 6 & $\begin{array}{c}7 \\
\text { always }\end{array}$ \\
\hline c) yourself losing an event & $\begin{array}{r}1 \\
\text { never }\end{array}$ & 2 & 3 & 4 & 5 & 6 & $\begin{array}{c}7 \\
\text { always }\end{array}$ \\
\hline
\end{tabular}

6. When you are imaging, how easily do you see?

$\begin{array}{lccccccc}\begin{array}{l}\text { a) isolated parts of a skill } \\ \begin{array}{l}1 \\ \text { bery difficult }\end{array}\end{array} & \begin{array}{c}1 \\ 1\end{array} & 2 & 3 & 4 & 5 & 6 & 6 \begin{array}{c}7 \\ \text { very easy } \\ \text { very difficult }\end{array} \\ \begin{array}{l}1 \\ \text { c) part of an event }\end{array} & \begin{array}{c}1 \\ \text { very difficult }\end{array} & \begin{array}{c}1 \\ \text { very easy }\end{array} \\ \text { d) entire event } & \text { very difficult } & 3 & 4 & 5 & 6 & \begin{array}{c}7 \\ \text { very easy }\end{array} \\ \end{array}$

7. When you are imaging, how often do you see: 


\begin{tabular}{|c|c|c|c|c|c|c|c|}
\hline $\begin{array}{l}\text { d) yourself doing a pre-event } \\
\text { routine (e.g., warm up) }\end{array}$ & $\begin{array}{r}1 \\
\text { never }\end{array}$ & 2 & 3 & 4 & 5 & 6 & $\begin{array}{c}7 \\
\text { always }\end{array}$ \\
\hline $\begin{array}{l}\text { e) the atmosphere of the } \\
\text { competition day }\end{array}$ & $\begin{array}{r}1 \\
\text { never }\end{array}$ & 2 & 3 & 4 & 5 & 6 & $\begin{array}{c}7 \\
\text { always }\end{array}$ \\
\hline f) yourself winning an event & $\begin{array}{r}1 \\
\text { never }\end{array}$ & 2 & 3 & 4 & 5 & 6 & $\begin{array}{c}7 \\
\text { always }\end{array}$ \\
\hline $\begin{array}{l}\text { g) yourself receiving a } \\
\text { first place eward }\end{array}$ & $\begin{array}{r}1 \\
\text { never }\end{array}$ & 2 & 3 & 4 & 5 & 6 & $\begin{array}{c}7 \\
\text { always }\end{array}$ \\
\hline
\end{tabular}

8. When you are using mental imagery to what extent do you actually foel yourself performing?

$\begin{array}{rrrrrrr}1 & 2 & 3 & 4 & 5 & 6 & \begin{array}{c}7 \\ \text { never }\end{array}\end{array}$

How easily do you foel:

a) contact with equipment

b) specific muscles

$\begin{array}{lllllll}\text { very difficult } & 2 & 3 & 4 & 5 & 6 & \begin{array}{c}7 \\ \text { very easy }\end{array}\end{array}$

c) body control

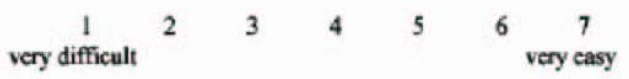

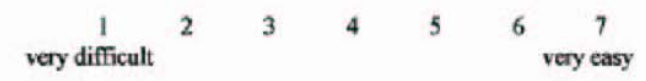

9. Are your imagery sessions structured (i.e., you know in advance what you will image and for how long)?

$\begin{array}{ccccccc}1 & 2 & 3 & 4 & 5 & 6 & \begin{array}{c}7 \\ \text { never }\end{array} \\ & & & & & & \text { always }\end{array}$

10. Are you imagery sessions regular (i.e., at a specific time each day)?

$\begin{array}{ccccccc}\begin{array}{c}1 \\ \text { never }\end{array} & 2 & 3 & 4 & 5 & 6 & \begin{array}{c}7 \\ \text { always }\end{array} \\ \text { (i.e., are spontaneous) } & & & & & \text { (i.e., very regular) }\end{array}$

11. In preparation for your all-time best performance, how much mental imagery did you do?

$\begin{array}{cccccccc}\begin{array}{c}1 \\ \text { less than } \\ \text { usual }\end{array} & 2 & 3 & 4 & 5 & 6 & \begin{array}{c}7 \\ \text { more than } \\ \text { usual }\end{array}\end{array}$



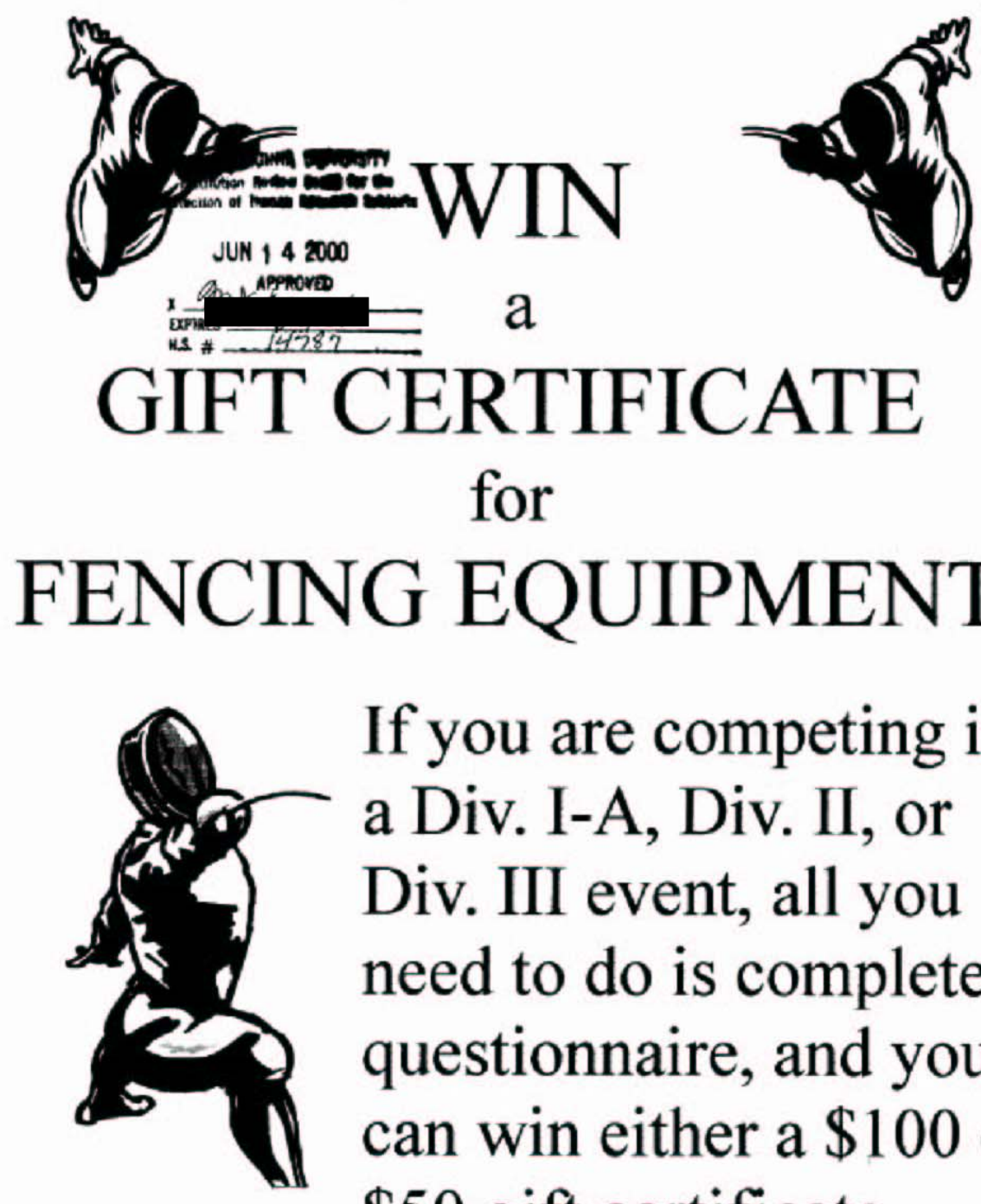

a

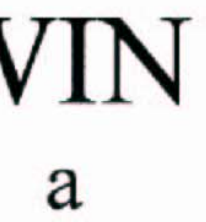

CERTIFICATE

for

FENCING EQUIPMENT

If you are competing in

a Div. I-A, Div. II, or

Div. III event, all you need to do is complete a questionnaire, and you can win either a $\$ 100$ or $\$ 50$ gift certificate.

If interested, please look for the WVU Questionnaire signs. You can complete the questionnaire anytime during the day. This is a research study developed by Jason Boron. 